\title{
Six new dactylogyrid species (Platyhelminthes, Monogenea) from the gills of cichlids (Teleostei, Cichliformes) from the Lower Congo Basin
}

\author{
Michiel W.P. Jorissen ${ }^{1,2, *}$, Antoine Pariselle ${ }^{3}$, Tine Huyse ${ }^{2,4}$, Emmanuel J. Vreven ${ }^{2,4}$, Jos Snoeks ${ }^{2,4}$, Eva Decru ${ }^{2,4}$, \\ Thomas Kusters ${ }^{1}$, Soleil Wamuini Lunkayilakio ${ }^{5}$, Fidel Muterezi Bukinga ${ }^{6}$, Tom Artois ${ }^{1}$, and Maarten P.M. Vanhove ${ }^{1,4,7,8}$ \\ ${ }^{1}$ Research Group Zoology: Biodiversity, \& Toxicology, Centre for Environmental Sciences, Hasselt University, \\ Agoralaan gebouw D, 3590 Diepenbeek, Belgium \\ 2 Royal Museum for Central Africa, Leuvensesteenweg 13, 3080 Tervuren, Belgium \\ 3 ISEM, Univ de Montpellier, CNRS, IRD, Montpellier, France \\ ${ }^{4}$ Laboratory of Biodiversity and Evolutionary Genomics, University of Leuven, Charles Deberiotstraat 42, 3000 Leuven, Belgium \\ ${ }^{5}$ Institut Supérieur Pédagogique, Mbanza-Ngungu, B.P. 127, Democratic Republic of the Congo \\ ${ }^{6}$ Centre de Recherche en Hydrobiologie, Uvira, B.P. 73, Democratic Republic of the Congo \\ 7 Department of Botany and Zoology, Faculty of Science, Masaryk University, Kamenice 735/5, 62500 Brno, Czech Republic \\ ${ }^{8}$ Zoology Unit, Finnish Museum of Natural History, University of Helsinki, Pohjoinen Rautatiekatu 13, 00100 Helsinki, Finland
}

Received 29 May 2018, Accepted 4 November 2018, Published online 7 December 2018

\begin{abstract}
The Lower Congo Basin is characterized by a mangrove-lined estuary at its mouth and, further upstream, by many hydrogeographical barriers such as rapids and narrow gorges. Five localities in the mangroves and four from (upstream) left bank tributaries or pools were sampled. On the gills of Coptodon tholloni, Coptodon rendalli, Hemichromis elongatus, Hemichromis stellifer and Tylochromis praecox, 17 species of parasites (Dactylogyridae \& Gyrodactylidae, Monogenea) were found, eight of which are new to science. Six of these are herein described: Cichlidogyrus bixlerzavalai n. sp. and Cichlidogyrus omari n. sp. from T. praecox, Cichlidogyrus calycinus n. sp. and Cichlidogyrus polyenso n. sp. from H. elongatus, Cichlidogyrus kmentovae n. sp. from H. stellifer and Onchobdella ximenae $\mathrm{n}$. sp. from both species of Hemichromis. On Cichlidogyrus reversati a ridge on the accessory piece was discovered that connects to the basal bulb of the penis. We report a putative spillback effect of the native parasites Cichlidogyrus berradae, Cichlidogyrus cubitus and Cichlidogyrus flexicolpos from C. tholloni to the introduced C. rendalli. From our results, we note that the parasite fauna of Lower Congo has a higher affinity with the fauna of West African and nearby freshwater ecoregions than it has with fauna of other regions of the Congo Basin and Central Africa.
\end{abstract}

Key words: Parasitology, biodiversity, biogeography, Cichlidogyrus, Cichlidae.

\begin{abstract}
Résumé - Six espèces nouvelles de Dactylogyridae (Platyhelminthes, Monogenea) parasites des branchies de cichlidés (Teleostei, Cichliformes) du bassin du Bas Congo. Le cours du Bas Congo est caractérisé par un estuaire bordé de mangroves et, plus en amont, par de nombreuses barrières hydro-géographiques formées de rapides ou de gorges étroites. Nous avons échantillonné dans cinq localités au niveau des mangroves et dans quatre autres en amont sur la rive gauche du fleuve, dans des affluents ou des étangs. Nous avons trouvé, sur les branchies de Coptodon tholloni, Coptodon rendalli, Hemichromis elongatus, Hemichromis stellifer et Tylochromis praecox, 17 espèces de parasites (Dactylogyridae et Gyrodactylidae, Monogenea), dont huit sont nouvelles pour la science. Six d'entre elles sont décrites ici : Cichlidogyrus bixlerzavalai n. sp. et Cichlidogyrus omari n. sp. sur T. praecox, Cichlidogyrus calycinus n. sp. et Cichlidogyrus polyenso n. sp. sur H. elongatus, Cichlidogyrus kmentovae n. sp. sur H. stellifer et Onchobdella ximenae n. sp. sur les deux espèces d'Hemichromis. Nous décrivons, chez Cichlidogyrus reversati, une arête sur la pièce accessoire qui la connecte avec l'ampoule basale basal du pénis. Nous notons un probable transfert latéral des espèces autochtones Cichlidogyrus berradae, Cichlidogyrus cubitus et Cichlidogyrus flexicolpos de C. tholloni vers l'espèce introduite $C$. rendalli. Nos résultats montrent que la faune parasitaire du Bas Congo présente plus d'affinités avec les faunes d'Afrique de l'Ouest ou des écorégions d'eau douce voisines, qu'avec celles des autres parties du bassin du Congo ou de l'Afrique Centrale.
\end{abstract}

*Corresponding author: michiel.jorissen@uhasselt.be

This is an Open Access article distributed under the terms of the Creative Commons Attribution License (http://creativecommons.org/licenses/by/4.0), which permits unrestricted use, distribution, and reproduction in any medium, provided the original work is properly cited. 


\section{Introduction}

The Lower Congo River (LCR) is $350 \mathrm{~km}$ long and extends from the Kintambo Rapids at the outlet of Pool Malebo to the Atlantic Ocean [2]. With its tributaries, the LCR forms the Lower Congo Basin, which contains the Lower Congo and the Lower Congo Rapids ecoregions. The Lower Congo ecoregion covers the LCR from its mouth to Matadi and the left-bank tributaries, the largest of which is the Inkisi River. At the mouth, a mangrove-lined estuary is found with euryhaline fishes and freshwater representatives of marine families. The Lower Congo Rapids ecoregion spans the LCR from Matadi to the Kintambo Rapids and the right-bank tributaries (see Fig. 1) [1]. The Lower Congo Rapids ecoregion is characterized by large rapids and canyons that are up to $200 \mathrm{~m}$ deep [24, 41]. This makes it the most hydrologically and spatially complex of the two ecoregions. Because of this complexity, there is a high habitat heterogeneity through numerous dispersal barriers. This and the downstream location in the Congo basin lead to the LCR having a hyperdiverse ichthyofauna with high levels of species endemism $[15,16]$. Of the over 320 fish species, 84 are documented endemics for the LCR [15]. The families Mochokidae, Cyprinidae and Cichlidae are the most speciesrich in the area [1]. The focus of this study is the taxonomic exploration of monogenean gill parasites (Platyhelminthes) of Cichlidae (Cichliformes: Teleostei) in the Lower Congo Basin. More specifically, representatives of Cichlidogyrus Paperna, 1960 (Dactylogyridae), Onchobdella Paperna, 1968 (Dactylogyridae) and Gyrodactylus Von Nordmann, 1832 (Gyrodactylidae) are likely to be observed, because they are known to infect African cichlids [34, 48]. Of these, Cichlidogyrus, with over 100 species described, is the most species-rich genus occurring on cichlids throughout Africa and the Middle East $[14,34,39,40]$. Species of Onchobdella are known from species of Hemichromis Peters, 1857, from Pelmatochromis buettikofferi (Steindachner, 1894) and Chromidotilapia guntheri (Sauvage, 1882) [31]. Onchobdella comprises eight species [4, 26, 30]. They occur mostly in West Africa, but have also been found in Cameroon [34]. Gyrodactylus includes 17 species known from African cichlids. This genus, however, is much larger, as over 450 species have been described and representatives are known to infect most fish orders $[12,48]$. The members of Onchobdella, Cichlidogyrus and Gyrodactylus are most easily distinguished through the morphology of the haptor, the caudal attachment organ, which includes sclerotized hooks and transverse bars. The haptor of species of Cichlidogyrus consists of seven pairs of hooks (I-VII), one pair of dorsal and one pair of ventral anchors associated with dorsal and ventral transverse bars. Hooks of pair II are always short and associated with the ventral anchors. Pairs I and III-VII can be short or elongated [32, 34, 46, 47]. The haptor of species of Onchobdella contains five to six pairs of short hooks, a pair of large dorsal anchors that are arranged distal-laterally, one pair of small ventral anchors associated with two ventral bars and one large horseshoe-shaped or straight dorsal bar [26, 34]. The hard parts in the haptor of species of Gyrodactylus comprise 16 marginal hooks and a pair of anchors that are connected by a superficial and deep ventral bar [38]. Species within these genera can be distinguished based on morphological differences between sclerotized structures, which are the male copulatory organ (MCO), the vagina (when sclerotized), and the haptoral sclerites. These parasite genera have not been thoroughly studied in the Lower Congo Basin, but parasites from the neighbouring Ogooué-Nyanga-Kouilou-Niari freshwater ecoregion (see Fig. 1) [1] were explored [30, 33]. These include Cichlidogyrus reversati Pariselle \& Euzet, 2003 and C. lemoallei Pariselle \& Euzet, 2003 from the mouth of the Lower Kouilou River (Republic of Congo, ROC), C. berradae Pariselle \& Euzet, 2003 from Lake Cayo and Loufoualéba, and C. legendrei Pariselle \& Euzet, 2003 and Scutogyrus chikhii Pariselle \& Euzet, 1995 from Lake Cayo. These parasites were collected from Pelmatolapia cabrae (Boulenger, 1899), except for Scutogyrus chikhii, which was described from the introduced Oreochromis mossambicus (Peters, 1852). In addition, Cichlidogyrus microscutus Pariselle \& Euzet, 1996 was found on Coptodon guineensis (Günther, 1862) from Lake Loufoualéba (see [32]). From the Congo River itself, Cichlidogyrus flexicolpos Pariselle \& Euzet, 1995 was described from Coptodon guineensis [29]. This study serves as a first exploration of the gill monogeneans of Coptodon tholloni (Poll \& Thys van den Audenaerde, 1960), Hemichromis elongatus (Guichenot, 1861), Hemichromis stellifer Loiselle, 1979 and Tylochromis praecox Stiassny, 1989. Parasites from C. rendalli have already been studied from the Bangwuelu-Mweru ecoregion [14, 46] and from Lake Kariba [7].

\section{Materials and methods}

During a field expedition to the Lower Congo region in June 2015, fish were collected from nine localities (see Fig. 1 and caption for the coordinates). Fish were caught using gill nets and euthanized with an overdose of MS222. All specimens were diagnosed in the field and later verified in the lab, except for the specimen of $T$. praecox, which was verified in the lab with a picture of the specimen, because it came from an existing collection from the Institut Supérieur Pédagogique de MbanzaNgungu and was not transported to the RMCA, Royal Museum for Central Africa. From each fish, the right gill arches were removed, stored on ethanol and used for parasitological screening. The storage fluid was also exhaustively screened. Parasites were collected with an entomological needle under a WILD M5 stereomicroscope (Wild, Heerbrugg, Switzerland), mounted on a glass slide and fixed with Malmberg's solution (in the field) or Hoyer's medium (in the lab). Coverslips were sealed with Glyceel [3], D-pex or nail polish. Parasites were identified through a Leitz Dialux 22 microscope (Leitz, Wetzlar, Germany) with differential interference contrast and measured with Auto-montage software (Imaging \& Microscopy, Weinheim, Germany). Images were taken with an optical camera on a Leica DM2500 microscope with Leica Application suite software V.X (Leica, Wetzlar, Germany). Illustrations were drawn using a drawing tube and finalized with GIMP V2.8 (www.gimp.org). The accessory piece and heel of the MCO are represented with a grey filling, to emphasize the plate-like structure and to distinguish it from the penis, which is a hollow duct. Measurements were carried out following Figure 2 and represented as average \pm standard deviation, individuals 


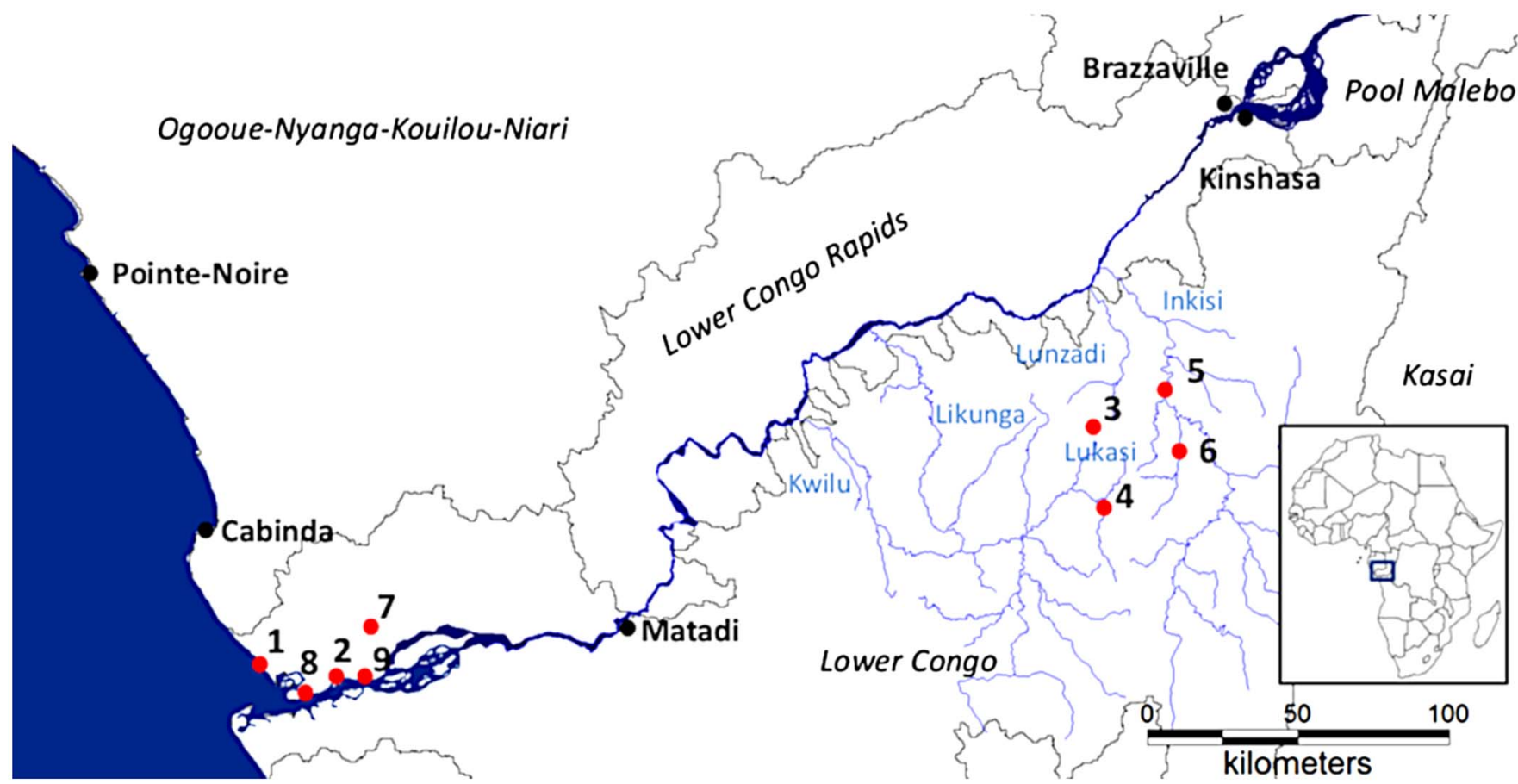

Figure 1. Overview of sampling localities (red dots) with the ecoregions in italics. Localities 3 and 5 are located within the cities MbanzaNgungu and Kisantu, respectively. The inset shows the Lower Congo region on the African continent. Sampling localities: 1, Tondé Estuary near Muanda $\left(05^{\circ} 57^{\prime} 35.9^{\prime \prime} \mathrm{S} 12^{\circ} 21^{\prime} 58.4^{\prime \prime} \mathrm{E}\right) ; 2$, Muila Kaku, mangroves near Lower Congo River $\left(05^{\circ} 59^{\prime} 33^{\prime \prime} \mathrm{S} 12^{\circ} 35^{\prime} 03.2^{\prime \prime} \mathrm{E}\right)$; 3, Ndimba Leta ponds, Mbanza-Ngungu, in between the Lunzadi and Lukasi rivers of which the latter flows into the Kwilu and Likunga $\left(05^{\circ} 15^{\prime} 10^{\prime \prime} \mathrm{S}\right.$ $\left.14^{\circ} 51^{\prime} 24^{\prime \prime} \mathrm{E}\right)$; 4, Pond near Kila Kindinga and Lukasi river $\left(5^{\circ} 29^{\prime} 7^{\prime \prime} \mathrm{S} 14^{\circ} 53^{\prime} 4^{\prime \prime} \mathrm{E}\right)$; 5, Inkisi River, off the Jardin botanique de Kisantu $\left(05^{\circ} 08^{\prime} 02^{\prime \prime} \mathrm{S} 15^{\circ} 03^{\prime} 52^{\prime \prime} \mathrm{E}\right)$; 6, Mvuazi River, Inkisi ( $\left.5^{\circ} 19^{\prime} \mathrm{S} 15^{\circ} 7^{\prime} \mathrm{E}\right)$; 7, Mbola River near Tshianya village $\left(05^{\circ} 52^{\prime} 09.8^{\prime \prime} \mathrm{S} 12^{\circ} 39^{\prime} 52.6^{\prime \prime} \mathrm{E}\right)$; 8 , Congo River near Nganda Flash station $\left(06^{\circ} 02^{\prime} 01.8^{\prime \prime} \mathrm{S} 12^{\circ} 31^{\prime} 48.2^{\prime \prime} \mathrm{E}\right)$, 9, Muila Nzenze, Kibamba village, mangroves near Congo River $\left(06^{\circ} 00^{\prime} 06.8^{\prime \prime} \mathrm{S} 12^{\circ} 40^{\prime} 27^{\prime \prime} \mathrm{E}\right)$. Rivers in blue.

measured (minimum value - maximum value). The standard deviation is only represented when $n \geq 30$. Numbering of the hooks follows Pariselle \& Euzet [33, 35]. Cichlids were deposited in the ichthyology collection of the RMCA in collections 2015-29 under accession numbers AB54005942, AB53952197 and AB54006866 and 2015-30 under RMCA_ Vert_2015.030.P.0009-0022. Individual accession numbers are represented in addendum 1. Whole-mounted parasites were deposited in the collections of the RMCA (M.T.38280-38375), the Natural History Museum (London, United Kingdom, NHMUK 2018.1.31.1-6), the Iziko South African Museum (Cape Town, South Africa, SAMC-A090065-69) and the Finnish Museum of Natural History (Helsinki, Finland, MZH, KN10043-10057). The MZH specimens can be consulted online through https://laji.fi/en/view?uri=luomus:KN.10043 and onwards. More hyperlinks and all accession numbers of parasites are given in Addendum 2.

\section{Results}

Seventeen species of monogeneans, eight of which are new to science, were found on five hosts (Table 1). For five described parasite species, this is their first record from the Lower Congo region, and for all of them, new host records were found. Six new species are described in the present study. In addition, morphological remarks are given for $C$. reversati, because the specimens in this study varied slightly from the original description. Additionally, more details on the connection of the accessory piece with the basal bulb of the penis in $C$. reversati were observed and mentioned under remarks.

\section{Cichlidogyrus bixlerzavalai Jorissen, Pariselle \& Vanhove n. sp.}

urn:lsid:zoobank.org:act:3E7C4017-8E0E-4DE3-A3BD6CD67D806601

Type host: Tylochromis praecox Stiassny, 1989.

Infection site: Gills.

Type locality: Muila Kaku, mangroves near Lower Congo River $05^{\circ} 59^{\prime} 33^{\prime \prime} \mathrm{S} 12^{\circ} 35^{\prime} 03.2^{\prime \prime} \mathrm{E}$.

Material: Four whole-mounted specimens in Malmberg's solution.

Holotype: M.T.38339.

Paratypes: M.T.38340-41, KN10053 https://laji.fi/en/ view?uri=luomus:KN.10053.

Etymology: The species epithet is a homage to singer Cedric Bixler-Zavala of bands At the drive-in, The Mars Volta and Antemasque and is a noun (name) in the genitive case.

Authorship: Note that the authors of the new taxon are different from the authors of this paper; Article 50.1 and 

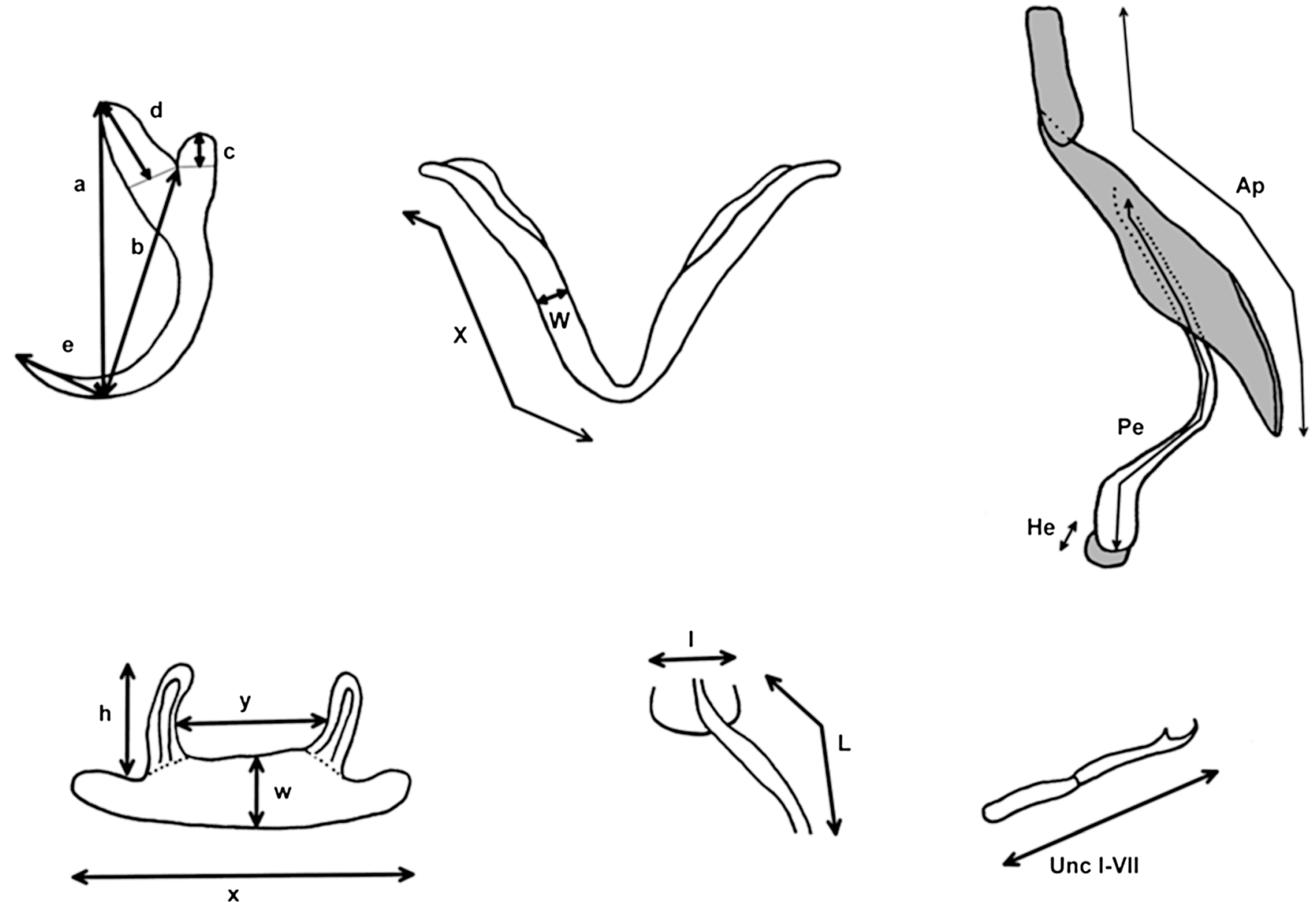

Figure 2. Schematic representation of the measurements taken of the hard parts of specimens of Cichlidogyrus and Onchobdella. Structures from top left to bottom right: anchor, ventral transverse bar, MCO, dorsal transverse bar, vagina and hook. Abbreviations: I-VII, hook length; a, total anchor length; Ap, length of accessory piece; b, blade length; c, shaft length; d, guard length, e, point length; h, auricle length; He, Heel length; 1, vagina width; L, vagina length; Pe, penis length; W, maximum width of ventral transverse bar; w, maximum width of dorsal transverse bar; $\mathrm{X}$, branch length of ventral transverse bar; $\mathrm{x}$, total length of dorsal transverse bar; $\mathrm{y}$, distance between auricles.

Recommendation 50A of International Code of Zoological Nomenclature [13].

\section{Description (Table 3, Figs. 3, 4a-4c)}

Dorsal anchors with guard length 4 to 5 times the shaft length. U-shaped indentation at the base. Point short and curved $(\mathrm{e}=11 \mu \mathrm{m})$. Ventral anchors $10 \mu \mathrm{m}$ smaller than dorsal ones. Blade equally long as in dorsal anchors, but base of the ventral anchors shorter, with deeper V-shaped indentation. Hooks pair I long ( $>1.7$ times the length of hooks pair II [35]), with rectangular-shaped shaft, slightly broader than the anterior, larval part. Hooks pair III-VII short $(<2$ times the length of hooks pair II [35]). Ventral transverse bar large $(X=53 \mu \mathrm{m})$ and broad $(\mathrm{W}=9 \mu \mathrm{m})$ with lateral extension on each arm. Extension long, covers around $70 \%$ of the length of each arm, except for the proximal and distal ends. Dorsal transverse bar with short auricles $(\mathrm{h}=12 \mu \mathrm{m})$, with usual morphology for species of Cichlidogyrus infecting species of Tylochromis (i.e. auricles in continuity with dorsal bar anterior face [23, 28]). Penis, thick-walled, tubular with a sinuous curve most proximally, followed by a $360^{\circ}$ loop. At the distal end, the penis curves approximately $60^{\circ}$. Basal bulb granulated. Heel absent. Accessory piece not directly connected to the basal bulb. It starts at the height of the loop, where it is club-shaped and ridged. Further distally, it narrows until it is thinner than the penis.

\section{Remarks}

Species of Cichlidogyrus that infect species of Tylochromis have reduced auricles on the dorsal transverse bar. The accessory piece does not connect to the basal bulb of the penis [23, 28]. However, a thin, filamentous connection was described for C. sigmocirrus Pariselle, Bitja Nyom, Bilong Bilong, 2014 and C. chrysopiformis Pariselle, Bitja Nyom, Bilong Bilong, 2014 [36], but with uncertainty. Both species were described from Tylochromis sudanensis Daget, 1954 from the Cross River in Cameroon [36]. Furthermore, all species have a tubular curved penis, referred to as a spirally-winding penis [23]. Cichlidogyrus bixlerzavalai n. sp. resembles C. muzumanii Muterezi Bukinga, Vanhove, Van Steenberge \& Pariselle, 2012 the most, as both species have large anchors with a long guard, elongated hooks pair I and a curved tubular 
Table 1. Occurrence of parasite species on their respective hosts, marked by an " $\mathrm{x}$ " and abundance of host and parasite, respectively.

\begin{tabular}{|c|c|c|c|c|c|c|}
\hline & C. tholloni & C. rendalli & H. elongatus & H. stellifer & T. praecox & $\mathrm{N}(171)$ \\
\hline $\mathrm{N}(14)$ & 5 & 3 & 4 & 1 & 1 & \\
\hline C. berradae* & & $\mathrm{H}$ & & & & 8 \\
\hline C. bixlerzavalai n. sp.* & & & & & $\mathrm{H}$ & 3 \\
\hline C. calycinus n. sp.* ${ }^{*}$ & & & $\mathrm{H}$ & & & 16 \\
\hline C. sp. $1^{*}$ & $\mathrm{x}$ & & & & & 3 \\
\hline C. sp. $2^{*}$ & $\mathrm{x}$ & & & & & 9 \\
\hline C. cubitus* & $\mathrm{H}$ & $\mathrm{H}$ & & & & 36 \\
\hline C. falcifer & & & $\mathrm{H}$ & & & 11 \\
\hline C. flexicolpos & & $\mathrm{H}$ & & & & 5 \\
\hline C. polyenso $\mathrm{n} . \mathrm{sp}{ }^{*}$ & & & $\mathrm{H}$ & & & 7 \\
\hline C. kmentovae n. sp.* & & & & $\mathrm{H}$ & & 5 \\
\hline C. longicirrus & & & $\mathrm{H}$ & & & 1 \\
\hline C. omari n. sp.* & & & & & $\mathrm{H}$ & 1 \\
\hline C. reversati & $\mathrm{H}$ & & & & & 8 \\
\hline C. tilapiae* $^{*}$ & $\mathrm{H}$ & & & & & 4 \\
\hline C. sp. & & $\mathrm{x}$ & $\mathrm{x}$ & & & 4 \\
\hline G. chitandiri* & $\mathrm{H}$ & & & & & 21 \\
\hline O. aframae* & & & $\mathrm{H}$ & & & 3 \\
\hline O. ximenae n. sp.* & & & $\mathrm{H}$ & $\mathrm{H}$ & & 25 \\
\hline$O . \mathrm{sp}$. & & & $\mathrm{x}$ & & & 1 \\
\hline
\end{tabular}

* Represents the first record of this species in Lower Congo. An "H" represents a new host record. "N" represents the number of hosts (2nd row) or parasites (last column).

Table 2. Number of parasite species per locality and infection intensity. Localities correspond to those in Figure 1. See Addenda 1 and 2 for the individual voucher and accession numbers.

\begin{tabular}{|c|c|c|c|}
\hline Host species & Parasite species & Locality & $\begin{array}{c}\text { Infection } \\
\text { intensity/no. } \\
\text { infected hosts }\end{array}$ \\
\hline \multirow[t]{9}{*}{ Coptodon tholloni } & C. sp. 1 & 9 & $3 / 1$ \\
\hline & C. sp. 2 & 9 & $9 / 1$ \\
\hline & C. cubitus & 4 & $1 / 1$ \\
\hline & & 5 & $1 / 1$ \\
\hline & & 8 & $1 / 1$ \\
\hline & & 9 & $5 / 1$ \\
\hline & C. reversati & 8 & $8 / 1$ \\
\hline & C. tilapiae & 3 & $4 / 1$ \\
\hline & G. chitandiri & 5 & $21 / 1$ \\
\hline \multirow[t]{3}{*}{ Coptodon rendalli } & C. berradae & 1 & $1-4 / 3$ \\
\hline & C. cubitus & 1 & $7-14 / 3$ \\
\hline & C. flexicolpos & 1 & $5 / 1$ \\
\hline \multirow{9}{*}{$\begin{array}{c}\text { Hemichromis } \\
\text { elongatus }\end{array}$} & C. calycinus $\mathrm{n}$. sp. & 4 & $3-6 / 3$ \\
\hline & & 6 & $2 / 1$ \\
\hline & C. falcifer & 4 & $1-10 / 2$ \\
\hline & & 6 & $1 / 1$ \\
\hline & C. polyenso $\mathrm{n} . \mathrm{sp}$. & 4 & $2-3 / 3$ \\
\hline & C. longicirrus & 4 & $1 / 1$ \\
\hline & $O$. aframae & 4 & $4 / 1$ \\
\hline & O. ximenae n. sp. & 4 & $1-8 / 1$ \\
\hline & & 6 & $3 / 1$ \\
\hline \multirow{2}{*}{$\begin{array}{l}\text { Hemichromis } \\
\text { stellifer }\end{array}$} & C. kmentovae n. sp. & 7 & $5 / 1$ \\
\hline & O. ximenae $\mathrm{n} . \mathrm{sp}$. & 7 & $1 / 1$ \\
\hline \multirow{2}{*}{$\begin{array}{l}\text { Tylochromis } \\
\text { praecox }\end{array}$} & C. bixlerzavalai $\mathrm{n}$. sp. & 2 & $4 / 1$ \\
\hline & C. omari n. sp. & 2 & $1 / 1$ \\
\hline
\end{tabular}

penis with an accessory piece at the distal end of the penis that runs to almost half of the length of the penis. The major difference between these species is that in C. muzumanii, the accessory piece engulfs the penis partially, while in $C$. bixlerzavalai $\mathrm{n}$. sp., the accessory piece lies separate from the penis. This has never been observed for species of Cichlidogyrus. It remains unclear if and where the accessory piece attaches to the penis in C. bixlerzavalai $\mathrm{n}$. sp. However, it is certain that the accessory piece does not connect to the basal bulb proximally and that the accessory piece does not engulf the distal end of the penis. One specimen has a bulge-shaped extension at the distal end of the penis, but this is probably an artefact, because it is an open structure, clearly observable and absent on other specimens. Additionally, the specimen with the extension is also the only one of which the distal end of the penis is oriented towards the accessory piece. It is observed on this specimen that at the $360^{\circ}$ loop the penis turns in the other direction. However, this directional change is likely the result of the flattening of the MCO. On one specimen, ridges at the proximal end of the accessory piece were not observed.

\section{Cichlidogyrus calycinus Kusters, Jorissen, Pariselle \& Vanhove n. sp.}

urn:lsid:zoobank.org:act:D4922EBE-7FBE-425C-BBF0C90E39DB7171

Type host: Hemichromis elongatus (Guichenot, 1861).

Infection site: Gills.

Type locality: Pond near Kila Kindinga $5^{\circ} 29^{\prime} 7^{\prime \prime} \mathrm{S}$ $14^{\circ} 53^{\prime} 3.8^{\prime \prime} \mathrm{E}$ 
Table 3. Measurements of Cichlidogyrus bixlerzavalai n. sp., C. omari n. sp. and C. reversati. Note the size difference in dorsal bar length, $\mathrm{x}$ between the two groups of $C$. reversati. All measurements in $\mu \mathrm{m}$ as the average \pm standard deviation, count and range (in parentheses).

\begin{tabular}{|c|c|c|c|c|}
\hline Species & C. bixlerzavalai $\mathrm{n} . \mathrm{sp}$. & C. omari n. sp. & C. reversati & C. reversati \\
\hline Host & T. praecox & T. praecox & C. tholloni & P. cabrae \\
\hline Locality & 2 & 2 & 8 & Mouth of Bas Koilou River, ROC \\
\hline Reference & Present study & Present study & Present study & Pariselle and Euzet [33] \\
\hline Number of specimens & 4 & 1 & 8 & 30 \\
\hline \multicolumn{5}{|l|}{ Ventral anchor } \\
\hline Total length, a & $40,3(39-41)$ & 32 & $43,8(41-45)$ & $44 \pm 2(40-49)$ \\
\hline Blade length, $b$ & $39,3(35-41)$ & 26 & $42,8(40-44)$ & $44 \pm 1.6(40-46)$ \\
\hline Shaft length, c & $2,3(1-3)$ & 4 & $4,8(3-7)$ & $3 \pm 1.3(1-9)$ \\
\hline Guard length, $d$ & $13,3(11-14)$ & 12 & $16,8(13-17)$ & $11 \pm 1.5(6-16)$ \\
\hline Point length, e & $11,3(9-12)$ & 7 & $17,8(16-19)$ & $16 \pm 1.3(13-19)$ \\
\hline \multicolumn{5}{|l|}{ Dorsal anchor } \\
\hline Total length, a & $50,3(49-51)$ & 31 & $57,8(55-60)$ & $59 \pm 1.9(53-63)$ \\
\hline Blade length, $b$ & $38,3(37-39)$ & 22 & $40,8(37-43)$ & $42 \pm 1.8(36-45)$ \\
\hline Shaft length, c & $4,3(3-5)$ & 6 & $4,8(2-6)$ & $4 \pm 1.8(2-14)$ \\
\hline Guard length, $d$ & $22,3(18-24)$ & 15 & $28,8(25-30)$ & $21 \pm 1.7(17-28)$ \\
\hline Point length, e & $11,3(10-11)$ & 8 & $14,8(13-16)$ & $14 \pm 1.1(11-16)$ \\
\hline \multicolumn{5}{|l|}{ Uncinuli } \\
\hline Length, I & $24,3(21-26)$ & 14 & $25,7(23-29)$ & $25 \pm 1.5(22-28)$ \\
\hline Length, II & $12,3(10-13)$ & 10 & $12,5(11-13)$ & $12 \pm 0.8(9-14)$ \\
\hline Length, III & $19,3(17-21)$ & 14 & $20,8(15-22)$ & $18 \pm 0.8(17-21)$ \\
\hline Length, IV & $21,3(21-22)$ & 19 & $23,8(20-27)$ & $22 \pm 0.9(20-25)$ \\
\hline Length, V & $21,3(21-22)$ & 23 & $25,8(23-28)$ & $24 \pm 1.3(20-27)$ \\
\hline Length, VI & $21,3(20-22)$ & 18 & $22,7(20-24)$ & $21 \pm 0.8(20-23)$ \\
\hline Length, VII & $19,3(16-22)$ & 17 & $19,6(18-23)$ & $19 \pm 0.9(15-20)$ \\
\hline \multicolumn{5}{|l|}{ Ventral bar } \\
\hline Branch length, $\mathrm{X}$ & $53,3(48-57)$ & 39 & $48,7(35-55)$ & $45 \pm 3.2(37-50)$ \\
\hline Maximum width, W & $9,3(8-10)$ & 5 & $8,7(7-11)$ & $9 \pm 1.4(6-13)$ \\
\hline \multicolumn{5}{|l|}{ Dorsal bar } \\
\hline Total, length, $\mathrm{x}$ & $59,3(57-61)$ & 62 & $57,7(53-64)$ & $46 \pm 2.3(42-51)$ \\
\hline Maximum width, w & $9,3(8-10)$ & 6 & $10,7(8-12)$ & $11 \pm 1.4(9-15)$ \\
\hline Distance between auricles, $\mathrm{y}$ & $17,3(15-18)$ & 8 & $20,7(13-24)$ & $15 \pm 2.4(12-24)$ \\
\hline Auricle length, $\mathrm{h}$ & $12,3(9-15)$ & 11 & $20,7(17-23)$ & $18 \pm 2.2(14-24)$ \\
\hline \multicolumn{5}{|l|}{$\mathrm{MCO}$} \\
\hline Penis length, $\mathrm{Pe}$ & $65,3(61-70)$ & 48 & $27,8(24-31)$ & $33 \pm 1.4(31-36)$ \\
\hline Length of accessory piece, AP & $26,2(22-32)$ & 58 & $32,8(28-34)$ & 1 \\
\hline Heel length, $\mathrm{He}$ & N.A. & 2 & N.A. & N.A. \\
\hline Length of accessory piece straight, Aps & & & $21,8(16-26)$ & $20 \pm 1.5(17-23)$ \\
\hline Total body length & $449,3(424-488)$ & 460 & $364,8(312-429)$ & $713 \pm 106(545-1011)$ \\
\hline
\end{tabular}

Other localities: Mvuazi River (Lower Congo) $5^{\circ} 19^{\prime} \mathrm{S}$ $15^{\circ} 7^{\prime} \mathrm{E}$.

Material: Fifteen whole-mounted specimens of which six are fixed in Hoyer's medium (including the holotype), the other nine in Malmberg's solution.

Holotype: M.T. 38316.

Paratypes: M.T. 38312-13, 38317-18, 38321, 38326, 38329, 38331, 38333, 38335, KN10046-47, https://laji.fi/en/view?uri= luomus:KN.10046 and https://laji.fi/en/view?uri=luomus:KN. 10047, SAMC-A090066, NHMUK 2018.1.31.1.

Symbiotype: RMCA_Vert_2015.030.P.0020.

Paratype host vouchers: RMCA_Vert_2015.030.P.0019, RMCA_Vert_2015.030.P.0021, RMCA_Vert_2015.030.P.0022.

Etymology: The species epithet in Latin refers to the cup-shaped distal end of the vagina (calyx, Latin: cup) and is an adjective.

Authorship: Note that the authors of the new taxon are different from the authors of this paper; Article 50.1 and
Recommendation 50A of International Code of Zoological Nomenclature [13].

\section{Description (Table 4, Figs. 4d-4f, 5)}

Dorsal anchors, with long guard $(\mathrm{d}=17 \mu \mathrm{m})$, which is more than twice the shaft length $(\mathrm{d}=7 \mu \mathrm{m})$. Blade long and curved. Ventral anchors on average $4 \mu \mathrm{m}$ smaller than dorsal anchors, but with longer point. Hooks I and V long. Hooks III-IV and VII-VII sometimes long, sometimes short. Ventral transverse bar with small extension at distal third of each arm. Dorsal transverse bar slightly concave, with developed, but rather short auricles $(\mathrm{h}=15 \mu \mathrm{m})$. Penis long, thin, tubular and makes a long turn of almost $360^{\circ}$ after leaving the basal bulb and ends near the middle of the distal plate of the accessory piece. Heel oval. Accessory piece proximally broader than penis and with bean-shaped extension at one sixth of the length, where accessory piece and penis meet. Further distally, 
Table 4. Measurements of Cichlidogyrus calycinus n. sp., C. teugelsi, C. polyenso n. sp., C. euzeti, C. kmentovae n. sp., C. cf. bychowskii and C. dracolemma. All measurements in $\mu$ m as the average \pm standard deviation, count and range (in parentheses).

\begin{tabular}{|c|c|c|c|c|c|c|c|}
\hline Species & $\begin{array}{l}\text { C. calycinus } \mathrm{n} . \\
\text { sp. }\end{array}$ & C. teugelsi & $\begin{array}{l}\text { C. polyenso } \mathrm{n} . \\
\text { sp. }\end{array}$ & C. euzeti & $\begin{array}{l}\text { C. kmentovae } \mathrm{n} \text {. } \\
\text { sp. }\end{array}$ & C. cf. bychowskii & C. dracolemma \\
\hline Host & H. elongatus & H. fasciatus & H. elongatus & H. fasciatus & H. stellifer & H. bimaculatus & H. letourneuxi \\
\hline Locality & $4 \& 6$ & $\begin{array}{l}\text { Kounougou River, Ivory } \\
\text { Coast }\end{array}$ & 4 & Benin \& Cameroon & 7 & $\begin{array}{l}\text { Congo River at Bokalaka, } \\
\text { DRC }\end{array}$ & $\begin{array}{l}\text { Niokolo Koba } \\
\text { River, }\end{array}$ \\
\hline Reference & Present study & Pariselle and Euzet [34] & Present study & $\begin{array}{l}\text { Dossou and Birgi } \\
{[6]}\end{array}$ & Present study & Messu Mandeng et al. [22] & $\begin{array}{l}\text { Řehulková et al. } \\
\text { [41] }\end{array}$ \\
\hline Number of specimens & 15 & 30 & 6 & 30 & 6 & 5 & 1 (Holotype) \\
\hline \multicolumn{8}{|l|}{ Ventral anchor } \\
\hline Total length, a & $35,7(30-38)$ & $36 \pm 1.1(33-38)$ & $40,4(37-43)$ & $40-45$ & $32,4(30-35)$ & $34(31-37)$ & 25 \\
\hline Blade length, $b$ & $30,7(26-33)$ & $31 \pm 1.4(29-34)$ & $38,4(37-39)$ & $30-35$ & $27,3(24-29)$ & $28(26-31)$ & 24 \\
\hline Shaft length, c & $7,7(4-12)$ & $5 \pm 1(3-7)$ & $4,4(2-5)$ & $8-10$ & $4,4(2-5)$ & $5(4-9)$ & 3 \\
\hline Guard length, $\mathrm{d}$ & $11,7(9-14)$ & $11 \pm 1.5(8-14)$ & $15,4(14-16)$ & $10-12$ & $13,4(12-15)$ & $10(9-14)$ & 8 \\
\hline Point length, e & $13,7(9-17)$ & $15 \pm 1.2(12-17)$ & $15,4(13-19)$ & $10-12$ & $12,4(10-15)$ & $12(10-13)$ & 9 \\
\hline \multicolumn{8}{|l|}{ Dorsal anchor } \\
\hline Total length, a & $39,7(33-43)$ & $41 \pm 1.6(35-45)$ & $46,4(43-47)$ & $40-50$ & $32,5(31-34)$ & $33(31-35)$ & 23 \\
\hline Blade length, $b$ & $26,7(22-28)$ & $27 \pm 1.2(25-31)$ & $31,4(29-33)$ & $28-30$ & $22,5(19-23)$ & $23(21-25)$ & 17 \\
\hline Shaft length, c & $7,6(5-10)$ & $5 \pm 0.9(3-7)$ & $5,4(2-7)$ & $8-10$ & $3,5(2-4)$ & $5(4-7)$ & 2 \\
\hline Guard length, d & $17,6(15-20)$ & $17 \pm 1.7(12-20)$ & $22,4(20-23)$ & $20-25$ & $16,5(15-18)$ & $13(10-15)$ & 12 \\
\hline Point length, e & $10,7(9-12)$ & $11 \pm 0.7(10-13)$ & $9,4(7-10)$ & $8-10$ & $9,5(9-10)$ & $9(6-10)$ & 6 \\
\hline \multicolumn{8}{|l|}{ Uncinuli } \\
\hline Length, I & $32,7(22-42)$ & $31 \pm 1.6(28-37)$ & $43,4(38-47)$ & $35-40$ & $32,4(29-34)$ & $34(33-37)$ & I \\
\hline Length, II & $9,2(8-9)$ & $10 \pm 0.5(9-12)$ & $10,3(9-11)$ & 10 & $10,4(10-11)$ & $11(11-11)$ & 11 \\
\hline Length, III & $17,5(13-21)$ & $18 \pm 1.2(17-23)$ & $21,4(19-22)$ & $15-20$ & $20,4(19-22)$ & $21(19-22)$ & 17 \\
\hline Length, IV & $19,5(15-23)$ & $20 \pm 1.5(18-25)$ & $22,4(20-23)$ & $15-20$ & $23,4(22-26)$ & $22(20-23)$ & 16 \\
\hline Length, V & $25,6(21-31)$ & $24 \pm 1.2(21-29)$ & $24,4(22-27)$ & $15-20$ & $25,4(21-27)$ & $25(23-27)$ & 17 \\
\hline Length, VI & $20,6(16-23)$ & $21 \pm 1.1(19-23)$ & $25,4(20-28)$ & $15-20$ & $21,4(18-23)$ & $24(22-25)$ & 18 \\
\hline Length, VII & $17,6(13-21)$ & $18 \pm 0.8(16-20)$ & $22,4(21-25)$ & $15-20$ & $20,4(19-22)$ & $22(20-23)$ & 16 \\
\hline \multicolumn{8}{|l|}{ Ventral bar } \\
\hline Branch length, $\mathrm{X}$ & $34,6(26-38)$ & $34 \pm 2.7(31-39)$ & $46,3(40-54)$ & 40 & $31,4(28-34)$ & $31(29-36)$ & 18 \\
\hline Maximum width, W & $5,6(3-6)$ & $6 \pm 0.5(4-7)$ & $6,4(5-7)$ & l & $5,4(4-5)$ & $4(3-5)$ & 3 \\
\hline \multicolumn{8}{|l|}{ Dorsal bar } \\
\hline Total, length, $\mathrm{x}$ & $40,6(31-55)$ & $35 \pm 1.7(32-38)$ & $50,3(41-58)$ & 45 & $37,5(34-43)$ & $36(31-40)$ & 22 \\
\hline Maximum width, w & 7, $6(5-9)$ & $8 \pm 0.9(7-10)$ & 8, $4(6-11)$ & l & $7,5(6-8)$ & $7(6-8)$ & 5 \\
\hline Distance between auricles, y & $15,6(12-25)$ & $12 \pm 1(10-13)$ & $23,3(20-27)$ & 20 & $12,5(11-16)$ & $12(9-14)$ & 10 \\
\hline Auricle length, $\mathrm{h}$ & $10,6(9-15)$ & $11 \pm 1.2(8-14)$ & $12,4(11-13)$ & $10-12$ & $9,5(8-11)$ & $9(8-11)$ & 5 \\
\hline \multicolumn{8}{|l|}{$\mathrm{MCO}$} \\
\hline Penis length, $\mathrm{Pe}$ & $104,6(77-119)$ & $99 \pm 4.3(90-111)$ & $256,5(225-284)$ & $375-390$ & $137,5(103-187)$ & $185(108-203)$ & 95 \\
\hline Length of accessory piece, AP & $52,7(36-63)$ & $74 \pm 3.9(69-87)$ & $127,5(112-163)$ & 130 & $77,4(65-88)$ & $185(108-203)$ & 51 \\
\hline Heel length, $\mathrm{He}$ & $14,5(4-24)$ & 1 & $4,5(3-5)$ & / & $3,5(2-4)$ & $3(2-5)$ & 1 \\
\hline \multicolumn{8}{|l|}{ Vagina } \\
\hline Vagina length, L & 85,7 (67-105) & $72 \pm 7.2(61-88)$ & 129 & I & 29 & N.A. & 46 \\
\hline vagina width, 1 & 4, $7(3-6)$ & $3 \pm 0.3(3-4)$ & 1 & / & 1 & l & 1 \\
\hline Total body length & 1 & $528 \pm 55.9(403-605)$ & $497,5(436-583)$ & $600-700$ & / & 1 & 1 \\
\hline
\end{tabular}


VA
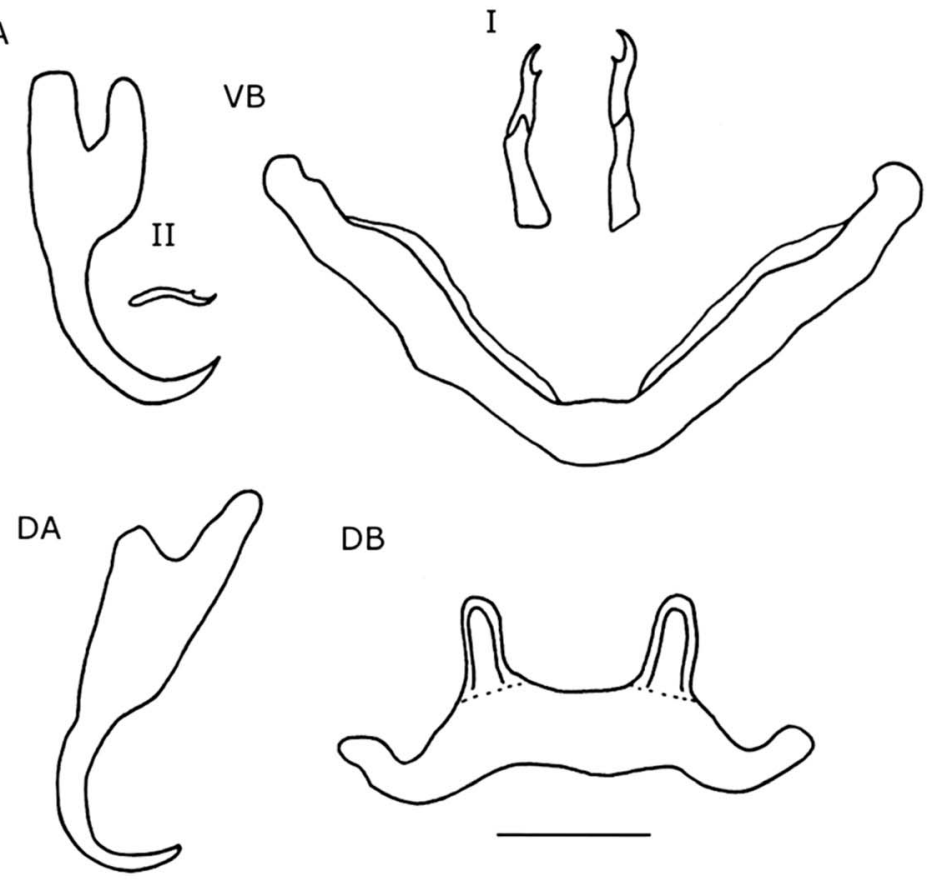

DB

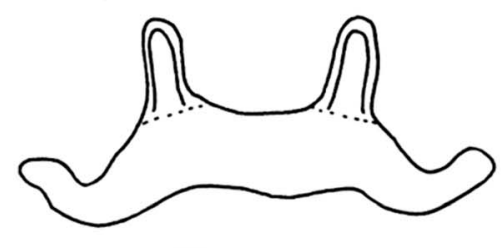

Figure 3. Haptoral and genital hard parts of Cichlidogyrus bixlerzavalai $\mathrm{n}$. sp. from Tylochromis praecox. Accessory piece of the MCO in grey, to highlight the plate-like structure of the accessory piece. I-VII, hooks; AP, accessory piece; DA, dorsal anchors; DB, dorsal transverse bar; MCO, male copulatory organ; Pe, penis; VA, ventral anchors; VB, ventral transverse bar. Scale bar: $20 \mu \mathrm{m}$.

the accessory piece narrows to the width of the penis and follows its trajectory, but ends further distally. Accessory piece ends distally in an irregularly-shaped plate. Distal plate with separate elongated structure in the middle. The plate itself is twice as long as it is broad and with rounded edges. Elongated structure longer than plate and reaches further proximally than plate. Proximal from where the elongation overshoots the plate, it touches the penis and narrow part of the accessory piece. Vagina large and tubular. Distally, the vagina has a forcepsshaped structure, engulfed by a semi-hollow structure, which resembles the cup of a flower. More proximally, the forcepslike structure thickens after which it narrows into a long and narrow tube. At the proximal end, the vagina makes a loop and broadens slightly.

\section{Remarks}

In general, the morphology of the haptor of species of Cichlidogyrus that infect species of Hemichromis hardly varies $[22,34]$. Thus, the morphology and measurements of the haptoral sclerites of $C$. calycinus n. sp. are nearly identical to that of $C$. teugelsi Pariselle \& Euzet, 2004. The main distinction in these structures is that the dorsal bar of $C$. calycinus n. sp. is larger $(\mathrm{x}=40 \mu \mathrm{m}, 31-55 \mu \mathrm{m}, \mathrm{n}=15)$ than that of C. teugelsi $(\mathrm{x}=35 \mu \mathrm{m}, 32-38 \mu \mathrm{m}, \mathrm{n}=30)$. The major morphological differences between the two are found on the $\mathrm{MCO}$ and vagina. Both have a long tubular penis that almost makes a $360^{\circ}$ turn and an accessory piece with a bean-shaped extension at $1 / 6$ of its length. Both species differ at the distal end of the accessory piece. In $C$. teugelsi, at the distal end the accessory piece makes a loop, while in C. calycinus n. sp. it forms an irregularly-shaped plate with an elongated structure attached to it. Furthermore, the narrow part of the accessory piece in $C$. calycinus n. sp. reaches further distally than that in C. teugelsi, which broadens and forms the loop structure at $5 / 6$ of the length of the penis. Also, the accessory piece is on average $22 \mu \mathrm{m}$ longer in C. teugelsi than in C. calycinus n. sp., while the penes differ $5 \mu \mathrm{m}$ in length, with $C$. calycinus n. sp. having the longer one $(\mathrm{Pe}=104 \mu \mathrm{m})$. The heel of $C$. teugelsi is irregularly shaped, whilst that of $C$. calycinus $\mathrm{n}$. $\mathrm{sp}$. is oval shaped. In some specimens of $C$. calycinus n. sp., the heel seemed longer. The vaginae of both species are also similar in morphology and size as they are long, tubular structures that make a loop at their proximal end. However, the distal ends are different. In $C$. teugelsi the distal end is a slightly sclerotized plate, while in C. calycinus n. sp. there is a forceps-like structure and an overall cup shape.

\section{Cichlidogyrus polyenso Jorissen, Pariselle \& Vanhove n. sp.}

urn:lsid:zoobank.org:act:C1165346-CFFB-45C7-951E0D3E094084B9

Type host: Hemichromis elongatus (Guichenot, 1861).

Infection site: Gills.

Type locality: Pond near Kila Kindinga $5^{\circ} 29^{\prime} 7^{\prime \prime} \mathrm{S}$ $14^{\circ} 53^{\prime} 3.8^{\prime \prime} \mathrm{E}$.

Material: four whole-mounted specimens in Malmberg's solution (including the holotype) and two in Hoyer's medium. 


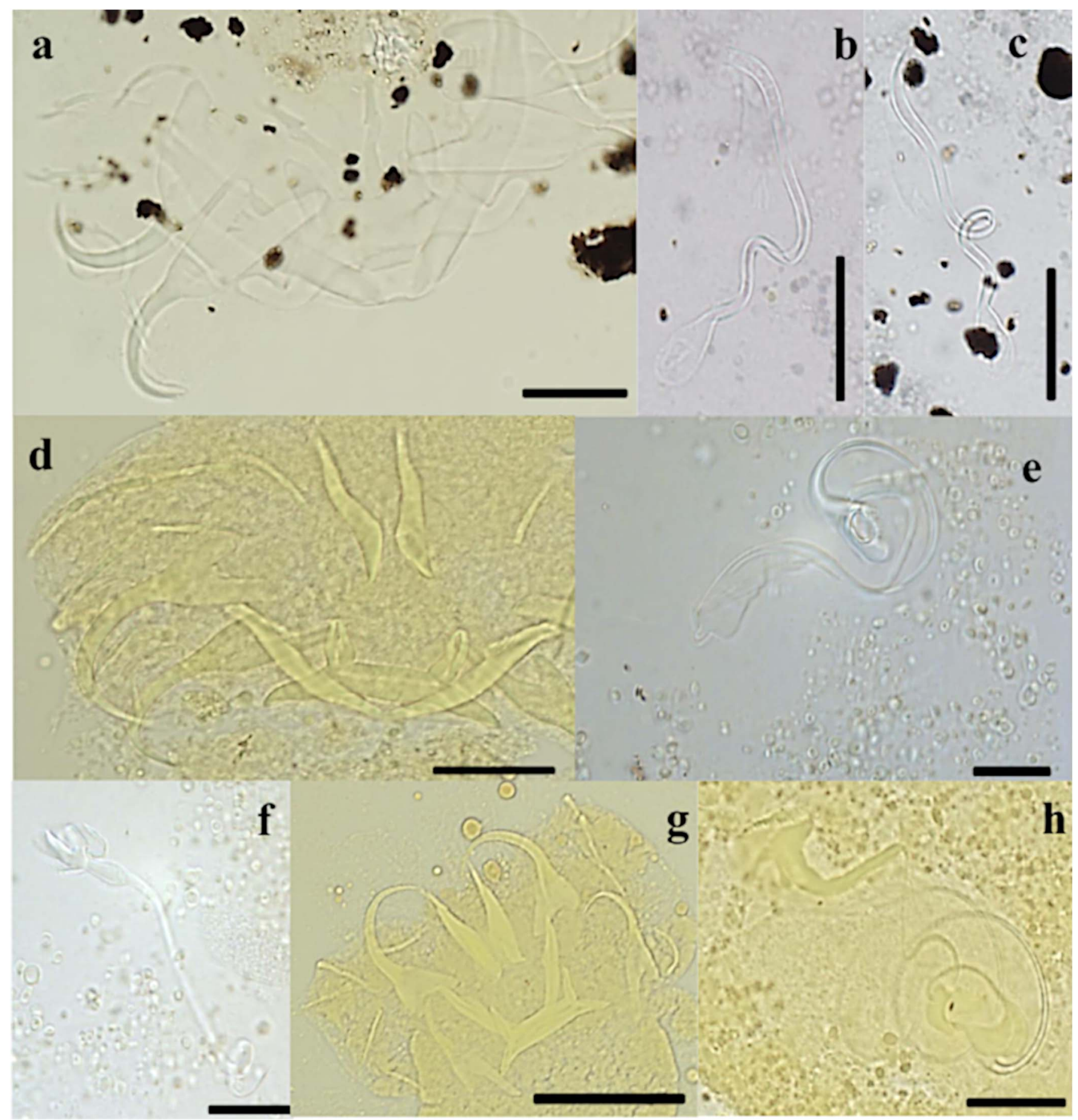

Figure 4. Compound micrographs of (a-c) Cichlidogyrus bixlerzavalai n. sp. from Tylochromis praecox: haptor of holotype (a), MCO of holotype (b) and MCO of paratype (c); of (d-f) Cichlidogyrus calycinus $\mathrm{n}$. sp. from Hemichromis elongatus: haptor of holotype (d), MCO of holotype (e), vagina of holotype (f); of $(\mathrm{g}-\mathrm{h})$ Cichlidogyrus polyenso $\mathrm{n}$. sp. from Hemichromis elongatus: haptor (g), MCO (h). Scale bar $20 \mu \mathrm{m}$, except for (g) $50 \mu \mathrm{m}$.

Holotype: M.T. 38330.

Paratypes: M.T. 38314-15, 38332, NHMUK 2018.1.31.3, KN10050 https://laji.fi/en/view?uri=luomus:KN.10050.

Symbiotype: RMCA_Vert_2015.030.P.0021.

Paratype host vouchers: RMCA_Vert_2015.030.P.0019, RMCA_Vert_2015.030.P.0020.
Etymology: Species epithet is derived from Zen Buddhism and the Japanese language where an enso is a hand-drawn circle. This refers to the shape of the penis, as it is coiled. Species epithet consists of a prefix and a noun.

Authorship: Note that the authors of the new taxon are different from the authors of this paper; Article 50.1 and 

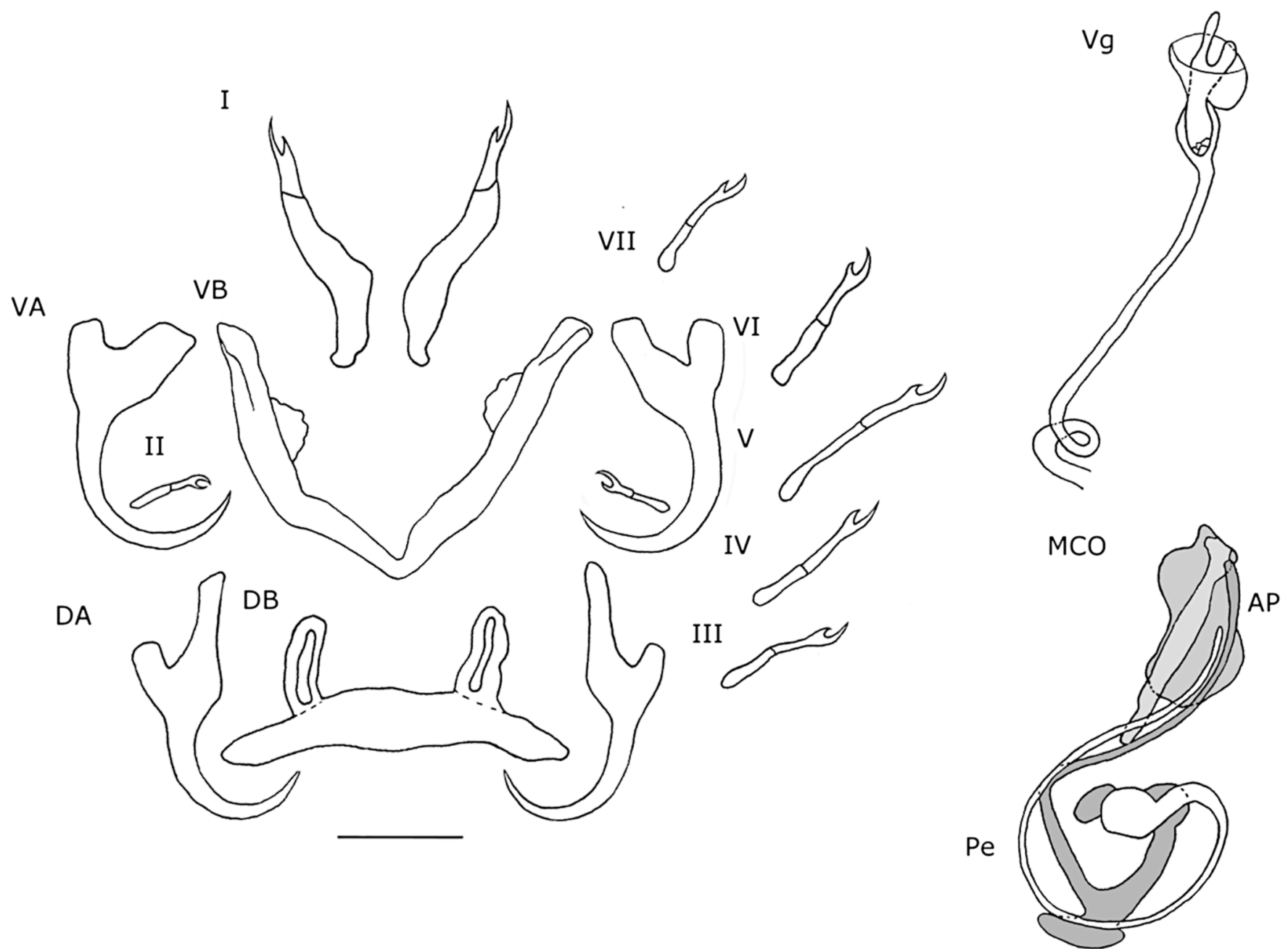

Figure 5. Haptoral and genital hard parts of Cichlidogyrus calycinus n. sp. from Hemichromis elongatus. Accessory piece of the MCO in grey, to highlight the plate-like structure of the accessory piece. I-VII, hooks; AP, accessory piece; DA, dorsal anchors; DB, dorsal transverse bar; MCO, male copulatory organ; Pe, penis; VA, ventral anchors; VB, ventral transverse bar; Vg, vagina. Scale bar: $20 \mu \mathrm{m}$.

Recommendation 50A of International Code of Zoological Nomenclature [13].

\section{Description (Table 4, Figs. 4g-4h, 6)}

Dorsal anchors with guard length four to five times the shaft length. Guard elongated and narrow. Point short $(\mathrm{e}=9 \mu \mathrm{m})$. Ventral anchors $6 \mu \mathrm{m}$ smaller than dorsal ones. Base with shallow, but wide indentation. Point long $(\mathrm{e}=15 \mu \mathrm{m})$. Hooks pair I elongated. Secondary shaft (see [35]) widens gradually and ends rounded. Hooks III-VII short. Dorsal transverse bar slightly concave with narrow auricles that are far apart $(y=23 \mu \mathrm{m})$. Ventral transverse bar V-shaped with small extension at $1 / 3$ of the distal ends of each arm. MCO with long tubular penis, which is spirally coiled and makes two to three loops. Distally from the loops, the penis makes a $90^{\circ}$ turn and continues straight before ending. Short, rectangular heel with rounded edges $(\mathrm{He}=4 \mu \mathrm{m})$. Accessory piece attaches to basal bulb, proximally broad but narrows distally of the basal bulb. Accessory piece makes two to three loops within the loops of the penis. Distally from the loops, the accessory piece leaves the space within the loops of the penis, turns $120^{\circ}$, meets the penis again and forms a plate resembling the tail of cetaceans, but with asymmetrical lateral ends and sides. At the proximal side, closest to the basal bulb, the plate is convex and results in a sharp point. The distal side is partially concave and partially convex and ends in a hooklike structure. The penis overshoots the plate and ends further distally. The vagina is large, tubular. Most proximally it corkscrews once, after which it makes a short loop. Soon after this it turns $180^{\circ}$ to stack two loops of tube after which it ends distally, shortly after leaving the coil.

\section{Remarks}

Cichlidogyrus polyenso $\mathrm{n}$. sp. has multiple characteristics in common with C. euzeti Dossou \& Birgi, 1984. Similarities are that both species have elongated hooks pair I, short hooks pairs III-VII, dorsal anchors with a long guard and short point, ventral anchors with a long point, a spirally-coiled penis, accessory piece and vagina. The major difference with C. euzeti is that the penis of C. polyenso n. sp. has fewer coils, two to three, rather than the four to five in C. euzeti, and is shorter in length. Moreover, the accessory piece is less coiled. 
VA

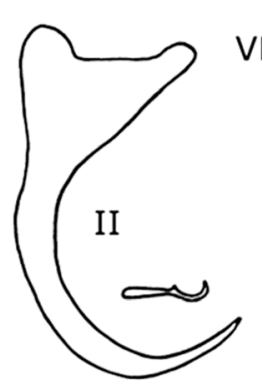

VB

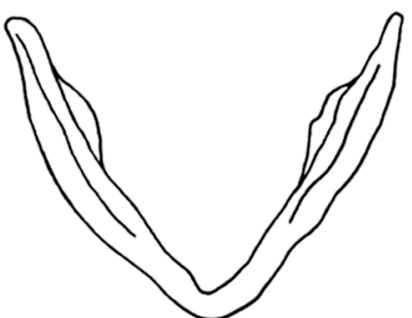

DA

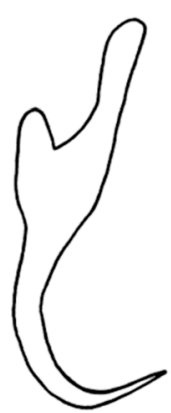

DB
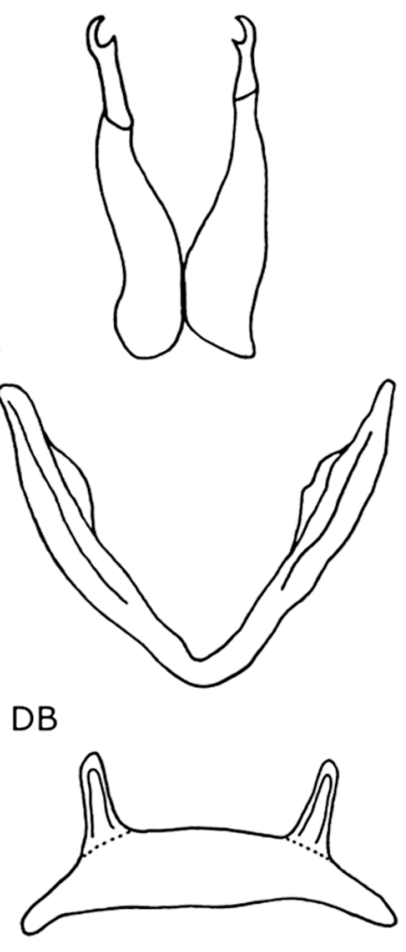

VII
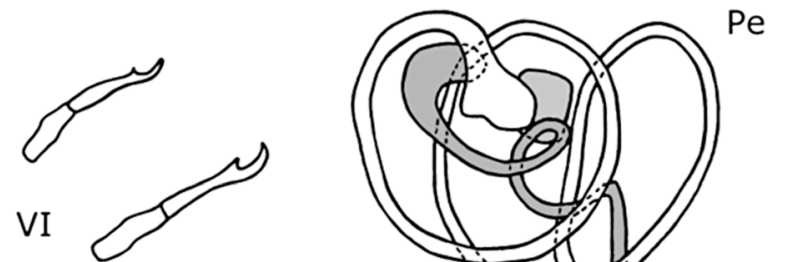

AP
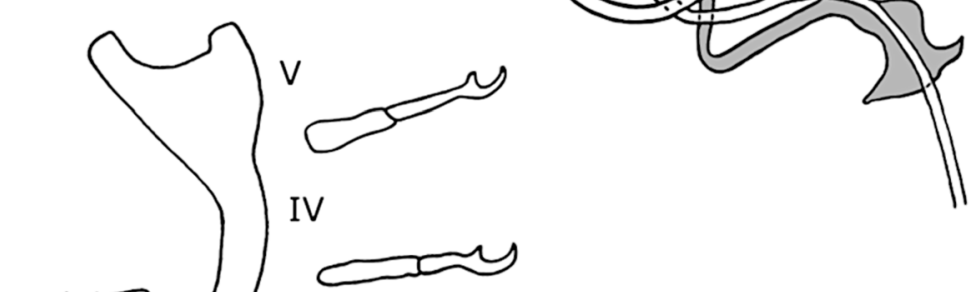

III

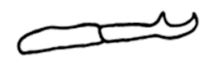

$\mathrm{Vg}$
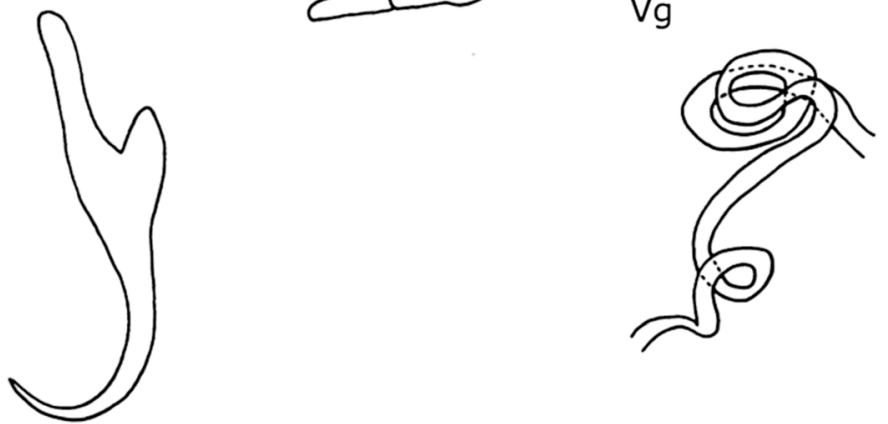

Figure 6. Haptoral and genital hard parts of Cichlidogyrus polyenso $\mathrm{n}$. sp. from Hemichromis elongatus. Accessory piece of the MCO in grey, to highlight the plate-like structure of the accessory piece. I-VII, hooks; AP, accessory piece; DA, dorsal anchors; DB, dorsal transverse bar; MCO, male copulatory organ; Pe, penis; VA, ventral anchors; VB, ventral transverse bar; Vg, vagina. Scale bar: $20 \mu \mathrm{m}$.

Additionally, the vagina in C. polyenso n. sp. is more compacted, because it coils, while the vagina of $C$. euzeti is a long tube that winds, but never coils. Also, C. polyenso $\mathrm{n}$. sp. has slightly larger ventral anchors $(\mathrm{b}=38 \mu \mathrm{m}, \mathrm{e}=15 \mu \mathrm{m})$ and hooks $(\mathrm{I}=43 \mu \mathrm{m}, \mathrm{V}=24 \mu \mathrm{m})$ than does $C$. euzeti $(\mathrm{b}=30-35 \mu \mathrm{m}$, $\mathrm{e}=10-12 \mu \mathrm{m}, \mathrm{I}=35-40 \mu \mathrm{m}, \mathrm{V}=15-20 \mu \mathrm{m})$. Cichlidogyrus euzeti is reported from Benin and Cameroon $[6,22]$ and the ROC [35]. Other species that have a similar sclerite morphology are C. longicirrus Paperna, 1965 and C. sanseoi Pariselle \& Euzet, 2004, both from H. fasciatus Peters, 1858 and the former from Chromidotilapia guentheri (Sauvage, 1882) as well, but both parasites have a longer MCO with more coils than do C. polyenso n. sp. and C. euzeti.

\section{Cichlidogyrus kmentovae Jorissen, Pariselle \& Vanhove n. sp.}

urn:lsid:zoobank.org:act:8A9E340B-2B30-428E-B994AB9E296F5DEC

Type host: Hemichromis stellifer Loiselle, 1979.

Infection site: Gills.
Type locality: Mbola River near Tshianya Village $05^{\circ} 52^{\prime} 09.8^{\prime \prime} \mathrm{S} 12^{\circ} 39^{\prime} 52.6^{\prime \prime} \mathrm{E}$.

Material: Six whole-mounted specimens in Malmberg's solution.

Holotype: M.T. 38338.

Paratypes: M.T. 38336-37, NHMUK 2018.1.31.5, SAMCA090068.

Symbiotype: AB53952197.

Etymology: Species epithet refers to biologist Nikol Kmentová (Czech Republic), an enthusiastic researcher on the monogenean fauna of Lake Tanganyika and is a noun (name) in the genitive case.

Authorship: Note that the authors of the new taxon are different from the authors of this paper; Article 50.1 and Recommendation 50A of International Code of Zoological Nomenclature [13].

\section{Description (Table 4, Figs. 7, 8a-8b)}

Dorsal anchors with elongated guard that is four to five times the shaft length. Indentation, smooth, convex up to the 

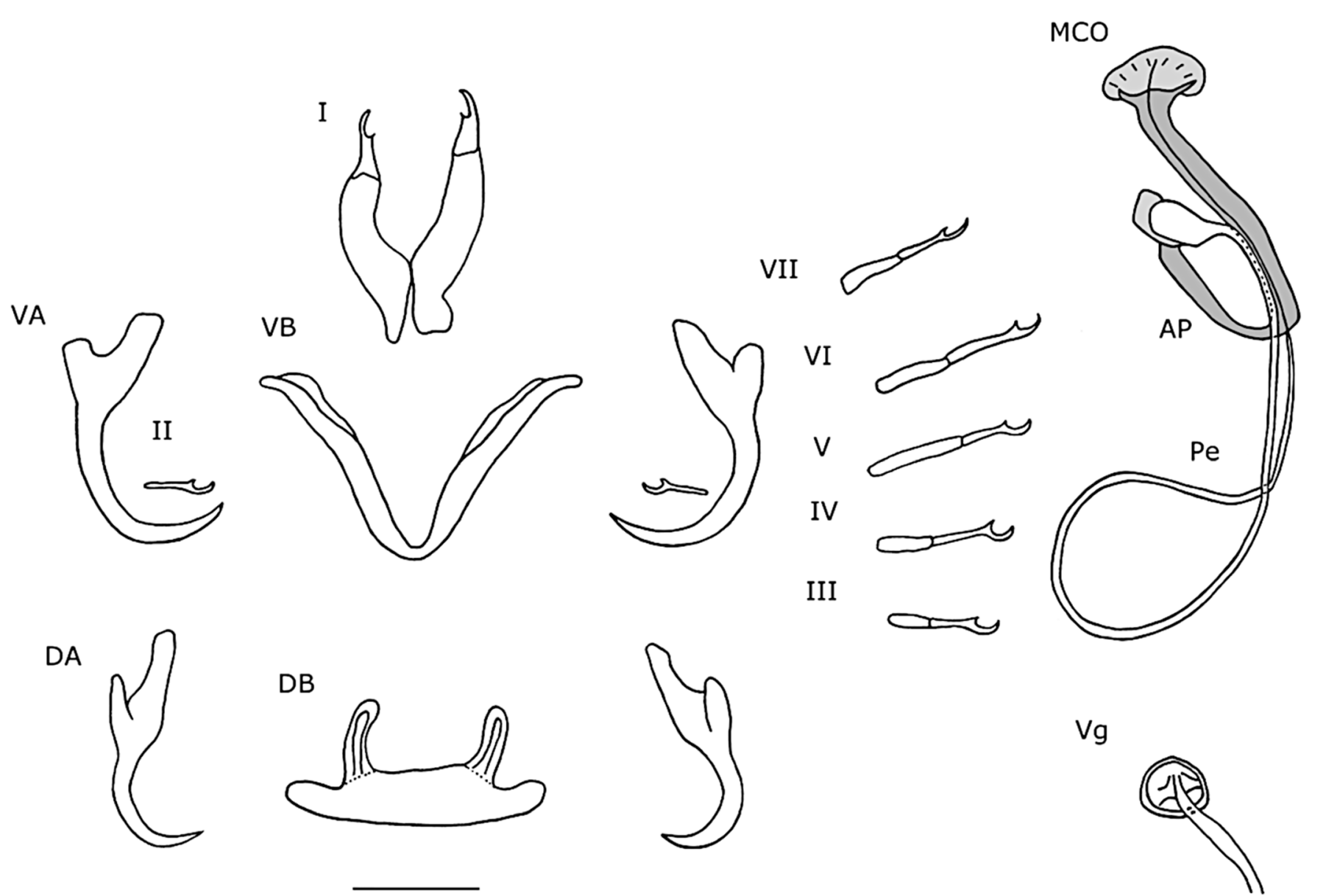

Figure 7. Haptoral and genital hard parts of Cichlidogyrus kmentovae n. sp. from Hemichromis stellifer. Accessory piece of the MCO in grey, to highlight the plate-like structure of the accessory piece. I-VII, hooks; AP, accessory piece; DA, dorsal anchors; DB, dorsal transverse bar; MCO, male copulatory organ; Pe, penis; VA, ventral anchors; VB, ventral transverse bar; Vg, vagina. Scale bar: $20 \mu \mathrm{m}$.

shaft. Short point $(\mathrm{e}=9 \mu \mathrm{m})$. Ventral anchors of same size $(\mathrm{a}=32 \mu \mathrm{m})$ but with a more robust blade and base. Guard shorter $(\mathrm{d}=13 \mu \mathrm{m})$. Indentation at the base less convex than in dorsal anchors. Hooks pair I large with broad primary shaft and even broader secondary shafts. Hooks pair IV-V long. Hooks pair VII short. Hooks VI of variable size, some long, some short. Pair III short and sometimes differs less than $0.2 \mu \mathrm{m}$ from twice the length of II. Dorsal transverse bar slightly concave with short extensions. Auricles developed, but short $(\mathrm{h}=9 \mu \mathrm{m})$. Ventral transverse bar small $(\mathrm{X}=31 \mu \mathrm{m})$ and narrow $(\mathrm{W}=5 \mu \mathrm{m})$ with extension that starts halfway along the course of each arm and reaches almost to the distal tip. MCO large with a long, thin, tubular penis $(\mathrm{Pe}=137 \mu \mathrm{m})$, which gradually narrows over its course and makes a large turn of $270^{\circ}$ at about the middle of its length. More distally, the penis turns $90^{\circ}$ and meets the accessory piece. Basal bulb with small rectangular heel with rounded edges $(\mathrm{He}=3 \mu \mathrm{m})$. Accessory piece departs from the basal bulb and makes a short $180^{\circ}$ turn after which it broadens and meets the penis. At the distal end, the accessory piece connects to a semi-circular plate with seven discernible grooves on its surface. At the junction between the semi-circular plate and the rest, two small, sharp extensions protrude towards the semi-circular plate. Vagina consists of a thick-walled bulbous structure connected to a tube.

\section{Remarks}

Cichlidogyrus kmentovae n. sp. closely resembles $C$. amieti Doussou \& Birgi, 1983; C. bychowskii sensu Paperna, 1965 and C. dracolemma Řehulková, Mendlová \& Šimková, 2013. Cichlidogyrus bychowskii was originally described by Markevitch, 1934 [17] as Ancyrocephalus bychowskii from the Leningrad aquarium from Hemichromis bimaculatus Gill, 1862. No type material was deposited and a drawing of the MCO and vagina was lacking [17]. However, the penis was described as a long tube that was coiled many times [17]. A redescription of $C$. bychowskii on new material from Southern Ghana from the same host species followed in 1965 by Paperna [25], this time with a drawing of all sclerotized structures. However, the penis was represented as a long tube that makes one large loop instead of multiple coils. Paperna did not address the difference in morphology of the penis and based his diagnosis on the total length of the animal and the morphology of some haptoral sclerites [25, 41]. Therefore, Messu Mandeng et al., Řehulková et al. [22, 41] and the present authors suspect that Paperna misidentified his specimens, which are different from $C$. bychowskii and represent a new species. Furthermore, because the description of Markevitch [17] is not sufficient to recognize the animal and fails to illustrate its 


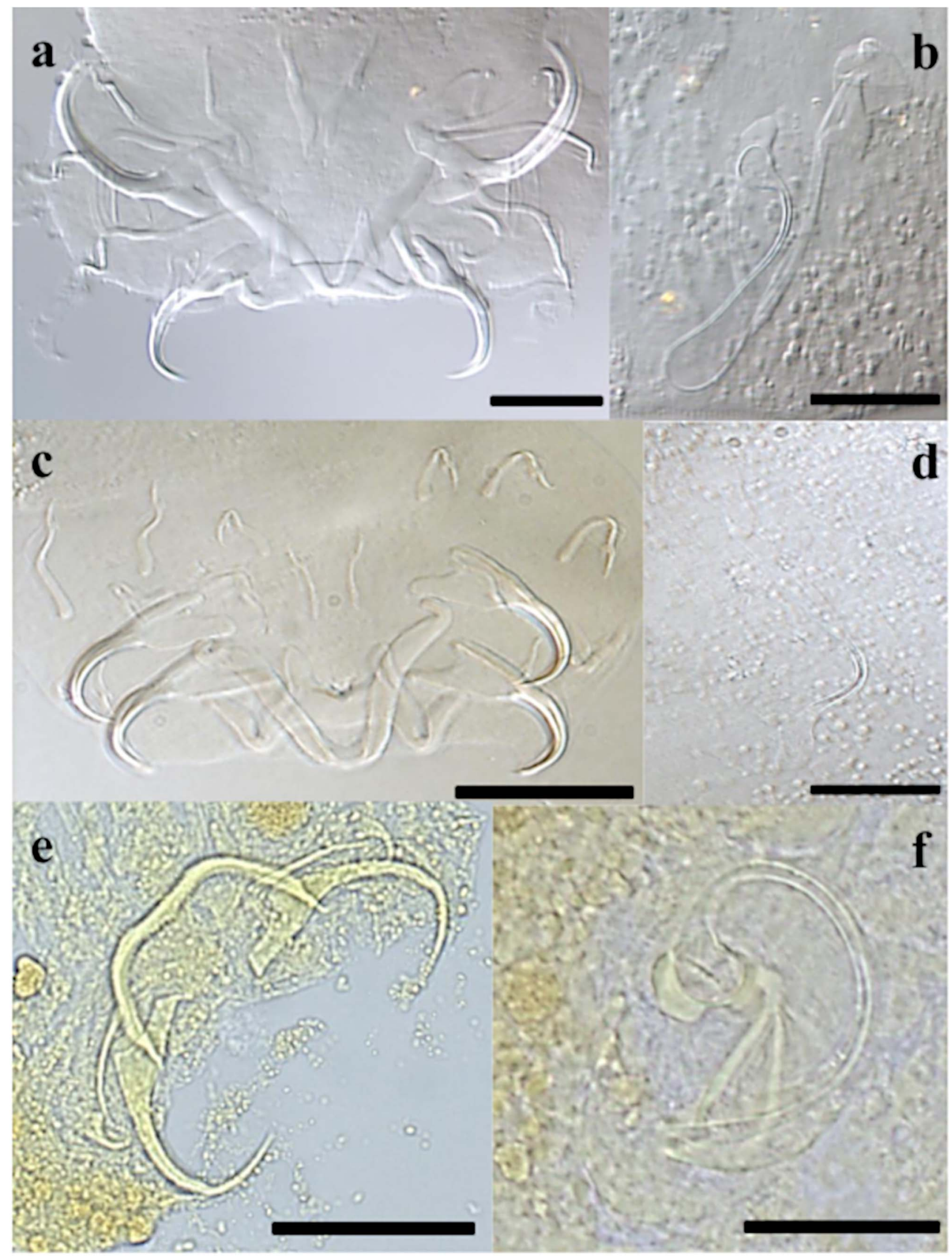

Figure 8. DIC micrographs of (a-b) Cichlidogyrus kmentovae n. sp. from Hemichromis stellifer: haptor (a), MCO (b); of (c-d) Cichlidogyrus omari n. sp. from Tylochromis praecox: haptor of holotype (c), MCO of holotype (d); compound micrographs of (e-f) Onchobdella ximenae n. sp. from Hemichromis elongatus: haptor (e), MCO (f). Scale bar $20 \mu \mathrm{m}$, except for (e) $50 \mu \mathrm{m}$. 
VA

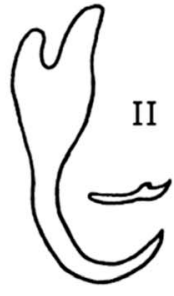

DA

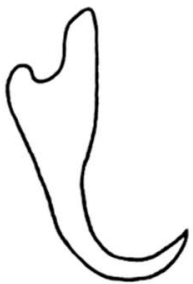

I

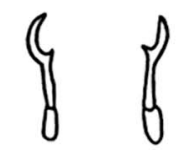

VB

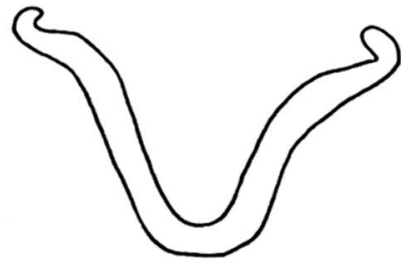

DB

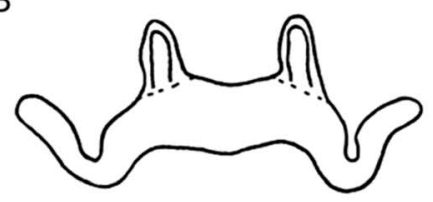

VII<smiles>C=O</smiles>

VI
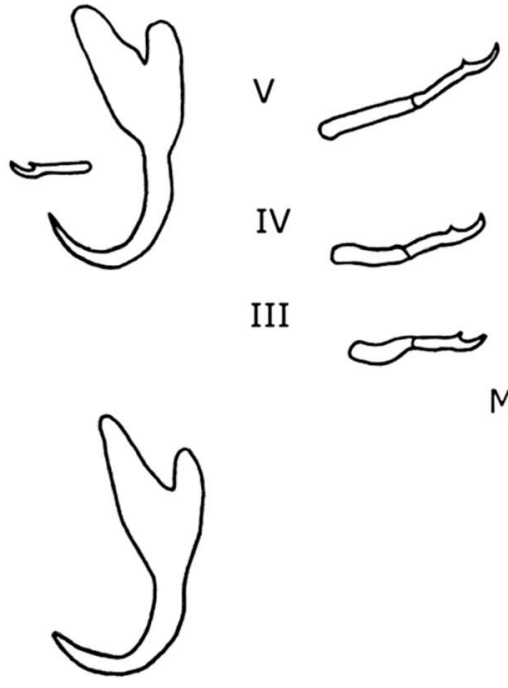

AP

MCO
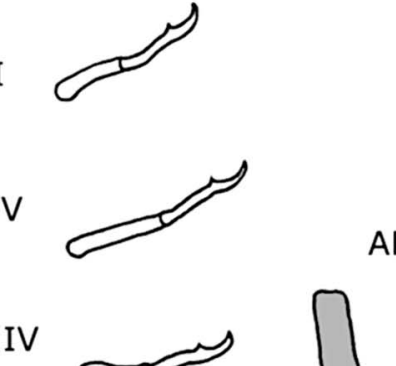

$\mathrm{Pe}$

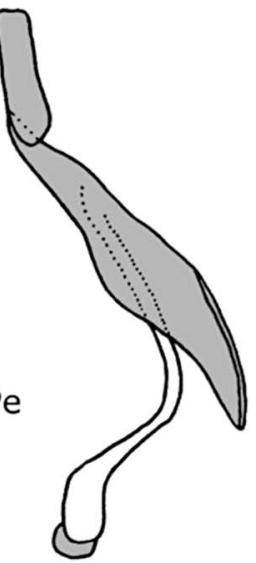

Figure 9. Haptoral and genital hard parts of Cichlidogyrus omari n. sp. from Tylochromis praecox. Accessory piece of the MCO in grey, to highlight the plate-like structure of the accessory piece. I-VII, hooks; AP, accessory piece; DA, dorsal anchors; DB, dorsal transverse bar; MCO, male copulatory organ; Pe, penis; VA, ventral anchors; VB, ventral transverse bar. Scale bar: $20 \mu \mathrm{m}$.

key characteristics, Cichlidogyrus bychowskii is considered a nomen dubium. It was previously considered a nomen nudum [22], but the term was misused. In Messu Mandeng et al. [22] specimens were found that resembled the species of Paperna, 1965 and were considered as C. cf. bychowskii. The present authors will use $C$. cf. bychowskii for the specimens described by Paperna, 1965 and collected by Messu Mandeng et al. [22] and stress that the species would need a new name in time, preferably, based on a description of new material. No voucher material was deposited by Paperna [25]. The difference between C. kmentovae n. sp. $(\mathrm{L}=29 \mu \mathrm{m})$ and $C$. amieti is that the vagina of $C$. amieti is longer $(\mathrm{L}=65-70 \mu \mathrm{m}$ from [5]) and the distal plate of the accessory piece is absent. Cichlidogyrus dracolemma and C. cf. bychowskii both have a distal plate, but the vagina of $C$. dracolemma is longer $(\mathrm{L}=46 \mu \mathrm{m})$ and thicker than in C. kmentovae n. sp. $(\mathrm{L}=29 \mu \mathrm{m})$. Both C. dracolemma and C. cf. bychowskii also have a broadened, irregularly-shaped distal plate with a large hook. In C. kmentovae n. sp. the distal plate is semi-circular and has grooves. Cichlidogyrus cf. bychowskii and C. kmentovae n. sp. both have a vagina with a circular, broadened proximal part, from which a thin, tubular structure extends to the genital pore, but in $C$. cf. bychowskii, this tube makes a $360^{\circ}$ loop. With regard to the length of the hooks, there was a categorical size difference in length between pairs III-VII, which is not mentioned in the descriptions of other species. However, the average length of pairs III and VI were short, whilst pairs IV-VI were long for C. cf. bychowskii [22]. In C. kmentovae n. sp., some measurements of hook pair III differed less than $0.2 \mu \mathrm{m}$ from twice the length of pair II. It is, therefore, not always straightforward to categorize the length of the hooks. Our sample size was limited, and thus a larger dataset of measurements should further clarify the discrepancy in hook lengths.

\section{Cichlidogyrus omari Jorissen, Pariselle \& Vanhove n. sp.}

urn:lsid:zoobank.org:act:73B533F8-2E50-4A01-BF8280DF705281CB

Type host: Tylochromis praecox Stiassny, 1989.

Infection site: Gills.

Type locality: Muila Kaku, mangroves near Lower Congo River $05^{\circ} 59^{\prime} 33^{\prime \prime} \mathrm{S} 12^{\circ} 35^{\prime} 03.2^{\prime \prime} \mathrm{E}$.

Material: One whole-mounted specimen fixed in Malmberg's solution.

Holotype: M.T. 38342.

Etymology: The species epithet is a homage to lead guitarist Omar Rodriguez-Lpez from bands At the drive-in, The Mars Volta, Antemasque, The Omar Rodriguez-Lopez group and Bosnian Rainbows and is a noun (name) in the genitive case.

Authorship: Note that the authors of the new taxon are different from the authors of this paper; Article 50.1 and Recommendation 50A of International Code of Zoological Nomenclature [13].

\section{Description (Table 3, Figs. 8c-8d, 9)}

Dorsal anchors small $(\mathrm{a}=31 \mu \mathrm{m})$ with a short point $(\mathrm{e}=7 \mu \mathrm{m})$. Ventral anchors of similar size $(\mathrm{a}=32 \mu \mathrm{m})$ with 
VA

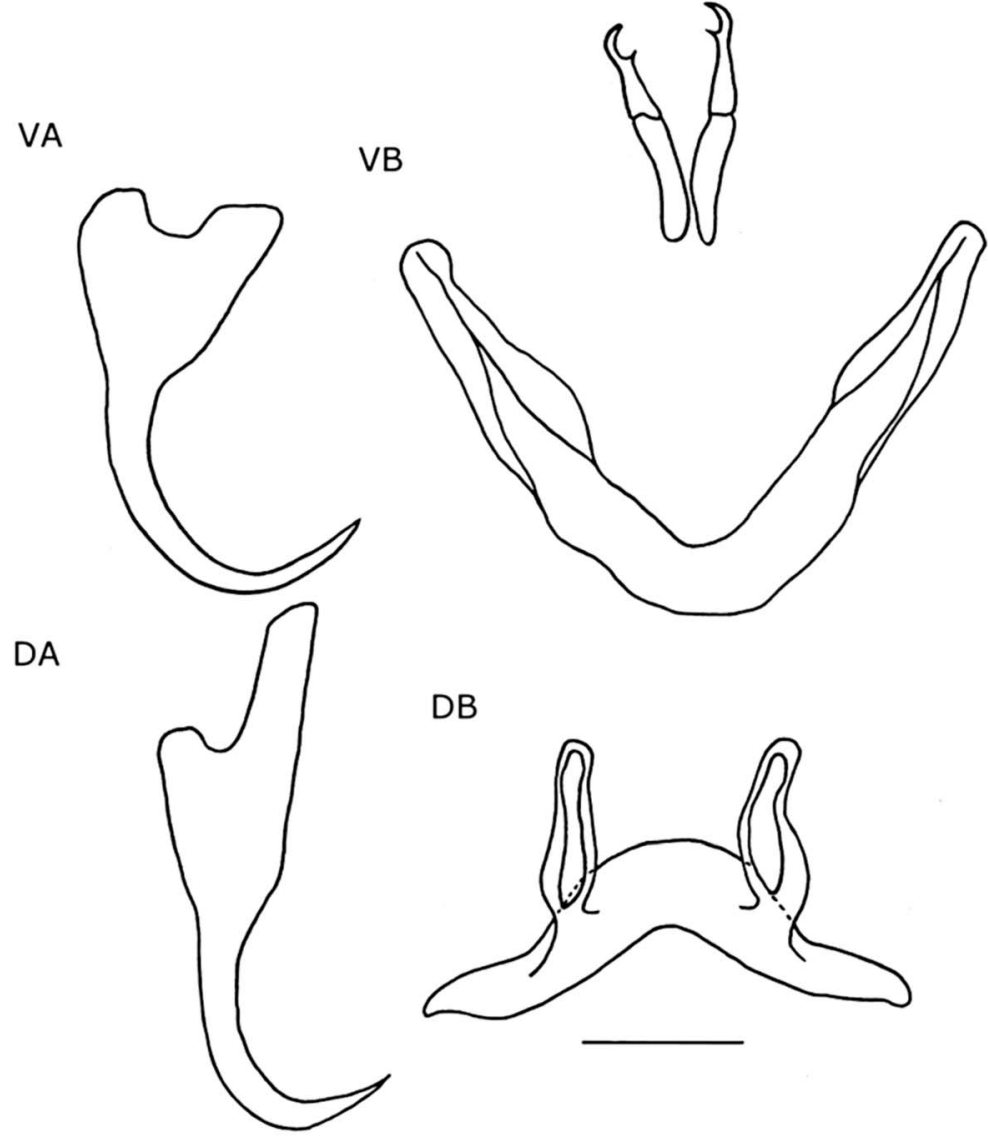

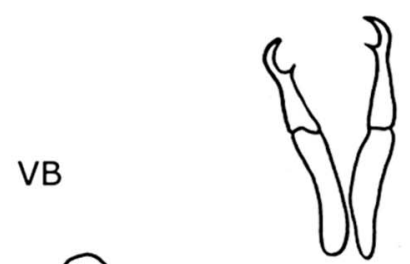

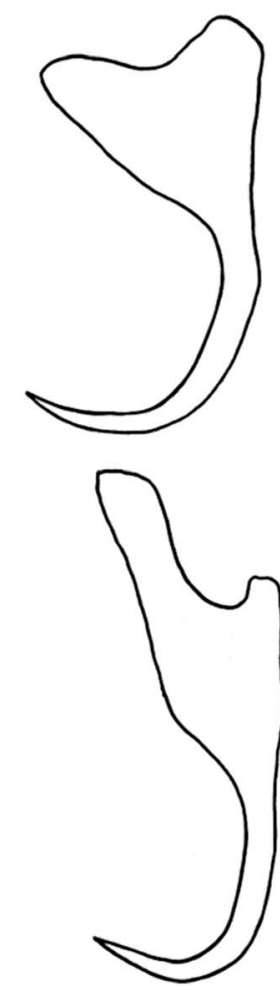

VII

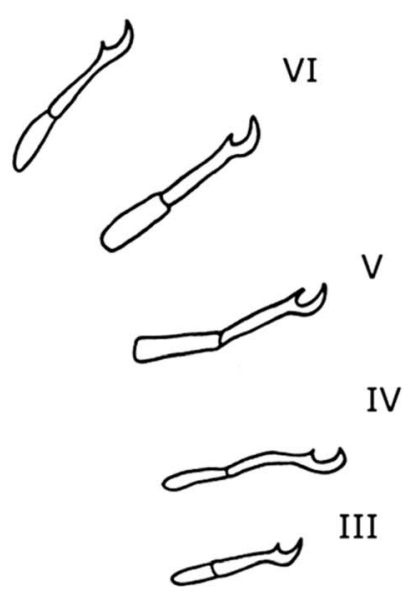

$\mathrm{MCO}$

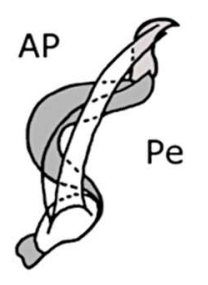

Figure 10. Haptoral and genital hard parts of Cichlidogyrus reversati from Coptodon tholloni. Accessory piece of the MCO in grey, to highlight the plate-like structure of the accessory piece. I-VII, hooks; AP, accessory piece; DA, dorsal anchors; DB, dorsal transverse bar; MCO, Male Copulatory Organ; Pe, penis; VA, ventral anchors; VB, ventral transverse bar. Scale bar: $20 \mu \mathrm{m}$.

a slightly longer point $(\mathrm{e}=8 \mu \mathrm{m})$ and a slightly bulkier base. All hooks are small. Ventral transverse bar small $(X=39 \mu \mathrm{m})$, thin $(\mathrm{W}=5 \mu \mathrm{m})$ and $\mathrm{V}$-shaped. Extension absent. Dorsal transverse bar with short, stubby auricles $(\mathrm{h}=11 \mu \mathrm{m})$. Penis has a rectangular basal bulb with rounded edges and a small rectangular heel with rounded edges. Penis is thin, tubular and curved. Accessory piece lies distally of the penis and consists of two parts, the most proximal one being a mantlelike structure that engulfs the penis at the height of the curvature and further distally from there. This mantle-like structure ends proximally in a point. Distally, it is connected to a second part, which is an elongated, blunt structure with rounded edges.

\section{Remarks}

Cichlidogyrus omari n. sp. has a small, rectangular heel, an accessory piece divided into two parts, and small transversal bars, anchors and hooks. These features have not been seen until now for species of Cichlidogyrus infecting Tylochromis spp. However, the accessory piece is large, mantle-shaped and partially engulfs the penis, which is also seen in $C$. kothiasi Pariselle \& Euzet, 1994; C. djietoi Pariselle, Bitja Nyom
\& Bilong Bilong, 2014; C. chrysopiformis and C. mulimbwai Muterezi Bukinga, Vanhove, Van Steenberge and Pariselle, 2012. Cichlidogyrus bixlerzavalai n. sp. and C. omari n. sp. are easily distinguishable by the size difference in ventral transversal bar, anchors and hooks pair I. Furthermore, C. omari n. sp. has a penis that is curved once and it has a large accessory piece that partially engulfs the penis, whilst C. bixlerzavalai $\mathrm{n}$. $\mathrm{sp}$. has a penis that makes one loop and has a smaller accessory piece with three indentations at the distal end. It is not common practice for species of Cichlidogyrus to be described based on a single specimen (see Cichlidogyrus sp. "T. polylepis 3" in [36]), but on the specimen of C. omari n. sp. all characters are discernible and are clearly different from already described species.

\section{Cichlidogyrus reversati Pariselle \& Euzet, 2003}

Type host: Tilapia cabrae Boulenger, 1899 (now Pelmatolapia cabrae).

Other hosts: Coptodon tholloni (Poll \& Thys van den Audenaerde, 1960).

Infection site: Gills.

Type locality: Mouth of Bas Kouilou River, Congo. 
Other localities: Congo River at Nganda Flash station $06^{\circ} 02^{\prime} 01.8^{\prime \prime} \mathrm{S} 12^{\circ} 31^{\prime} 48.2^{\prime \prime} \mathrm{E}$.

Material: Eight whole-mounted specimens in Malmberg's solution.

Vouchers: M.T. 38308-09, KN10043-45 https://laji.fi/en/ view?uri=luomus:KN.10043, https://laji.fi/en/view?uri=luomus: KN.10044, https://laji.fi/en/view?uri=luomus:KN.10045.

\section{Remarks (Table 3, Fig. 10)}

The eight recorded specimens of $C$. reversati from the Congo River had a dorsal bar length that was $9 \mu \mathrm{m}$ longer on average and a total length of half the size compared with the specimens from the type locality. In the original drawing (see [33]), the accessory piece connected with the heel through a thin filament. However, this connection was not observed in the specimens from Lower Congo. In three specimens, an extension of the heel in another focal plane was observed and could correspond with the thin filamentous connection of the original description. Additionally, in three specimens, the distal ends of the accessory piece and the penis did not meet. Also, in all specimens, it was observed that the accessory piece has a ridge, which separates the distal hook from the C-shaped part. This ridge continues towards the basal bulb as a filament. Most proximally, it forms a separate structure that attaches separately to the basal bulb. This ridge was also observed on one paratype of $C$. reversati on the slide RMCA37.402. However, the paratypes lost transparency due to the fixation in Malmberg's and were difficult to observe in detail. On the seven other paratypes and vouchers, all collected by Pariselle \& Euzet (2003) and deposited at the Royal Museum for Central Africa, Tervuren, Belgium, these structures were not observable. Because of this, the holotype, prepared with the same fixative, was not ordered from the Muséum national d'Histoire naturelle in Paris.

\section{Onchobdella ximenae Jorissen, Pariselle, Kusters \& Vanhove n. sp.}

urn:1sid:zoobank.org:act:826D2ABF-DB22-459B-80063BC12CEB8A6A

Type host: Hemichromis elongatus (Guichenot, 1861).

Other hosts: H. stellifer Loiselle, 1979.

Infection site: Gills.

Type locality: Pond Near Kila Kindinga $5^{\circ} 29^{\prime} 7^{\prime \prime} \mathrm{S}$ $14^{\circ} 53^{\prime} 3.8^{\prime \prime} \mathrm{E}$.

Other localities: Mvuazi River on H. elongatus $5^{\circ} 19^{\prime} \mathrm{S}$; $15^{\circ} 7^{\prime} \mathrm{E}$; Mbola River near Tshianya village on $H$. stellifer $05^{\circ} 52^{\prime} 09.8^{\prime \prime} \mathrm{S} 12^{\circ} 39^{\prime} 52.6^{\prime \prime} \mathrm{E}$.

Material: Three whole-mounted specimens in Hoyer's medium, including the holotype and 13 in Malmberg's solution.

Holotype: M.T. 38311.

Paratypes: M.T. 38319-20, 38324-25, 38327-28, 38334NHMUK 2018.1.31.2 and 2018.1.31.4, KN10049 https://laji.fi/en/view?uri=luomus:KN.10049 and 10052 https://laji.fi/en/view?uri=luomus:KN.10052, SAMC-372 A090065, A090067.

Symbiotype: RMCA_Vert_2015.030.P.0020.

Paratype host vouchers: RMCA_Vert_2015.030.P.0019, RMCA_Vert_2015.030.P.0021, RMCA_Vert_2015.030.P.0022, AB53952197.
Table 5. Measurements of Onchobdella ximenae n. sp. and $O$. voltensis. All measurements in $\mu \mathrm{m}$ as the average \pm standard deviation, count and range (in parentheses).

\begin{tabular}{|c|c|c|}
\hline Species & O. ximenae n. sp. & O. voltensis \\
\hline Host & $\begin{array}{l}\text { H. stellifer, } H \text {. } \\
\text { elongatus }\end{array}$ & $\begin{array}{l}\text { H. fasciatus, } H \text {. } \\
\text { bimaculatus }\end{array}$ \\
\hline Locality & $4,6 \& 7$ & Volta Lake \\
\hline Reference & Present study & Paperna [26] \\
\hline $\begin{array}{l}\text { Number of } \\
\text { specimens }\end{array}$ & 12 & 7 \\
\hline \multicolumn{3}{|c|}{ Ventral Anchor } \\
\hline $\mathrm{f}$ & $11,5(8-12)$ & $15-20$ \\
\hline \multicolumn{3}{|l|}{ Dorsal Anchor } \\
\hline $\mathrm{a}$ & $51,6(49-54)$ & $60-90$ \\
\hline $\mathrm{b}$ & $43,6(40-46)$ & I \\
\hline $\mathrm{c}$ & $2,6(1-3)$ & / \\
\hline $\mathrm{d}$ & $19,6(17-21)$ & $10-15$ \\
\hline $\mathrm{e}$ & $22,6(21-23)$ & I \\
\hline \multicolumn{3}{|l|}{ Uncinuli } \\
\hline uncinuli 1 & / & 10 \\
\hline uncinuli 2 & $13,2(12-13)$ & l \\
\hline uncinuli 3 & $13,3(12-15)$ & / \\
\hline uncinuli 4 & $13,3(12-14)$ & / \\
\hline uncinuli 5 & $13,4(11-13)$ & l \\
\hline uncinuli 6 & $13,6(11-15)$ & / \\
\hline \multicolumn{3}{|l|}{ Ventral Bars } \\
\hline $\mathrm{x}$ & $34,6(29-43)$ & $20-40$ \\
\hline \multicolumn{3}{|l|}{ Dorsal Bar } \\
\hline $\mathrm{x}$ & $50,5(31-69)$ & $70-100$ \\
\hline $\mathrm{h}$ & $33,5(29-41)$ & l \\
\hline $\mathrm{w}$ & $5,6(4-6)$ & $2-5$ \\
\hline \multicolumn{3}{|l|}{ MCO } \\
\hline pe & $66,7(60-70)$ & $30-50$ \\
\hline ap & $22,6(19-26)$ & $25-30$ \\
\hline he & $3,7(2-5)$ & N.A. \\
\hline \multicolumn{3}{|l|}{$\mathrm{Vg}$} \\
\hline $\mathrm{L}$ & $33,2(21-40)$ & N.A. \\
\hline 1 & $3,2(2-3)$ & N.A. \\
\hline
\end{tabular}

Etymology: The species epithet is a homage to Ximena Sariñana Rivera, a Mexican singer and is a noun (name) in the genitive case.

Authorship: Note that the authors of the new taxon are different from the authors of this paper; Article 50.1 and Recommendation 50A of International Code of Zoological Nomenclature [13].

\section{Description (Table 5, Figs. 8e-8f, 11)}

Dorsal anchors large $(\mathrm{a}=51 \mu \mathrm{m})$ and orientated distallaterally. Shaft undeveloped and bulbous $(\mathrm{c}=2 \mu \mathrm{m})$. Guard with rounded edges. Point long with sudden and well-marked thickening on the interior side of the curve. Ventral anchors ( $f=11 \mu \mathrm{m}$ ), with T-shaped base with rounded edges and a short, curved point. Dorsal bar slightly bent where both arms meet. Both arms make a $90^{\circ}$ turn distally and thicken slightly. Distal tip of each arm bulbously thickened. Two ventral bars, thin, near straight. Six pairs of small hooks of same size. MCO consists of a basal bulb with a long, tubular penis $(\mathrm{Pe}=$ $66 \mu \mathrm{m})$, which makes one large loop of almost $360^{\circ}$ along its 


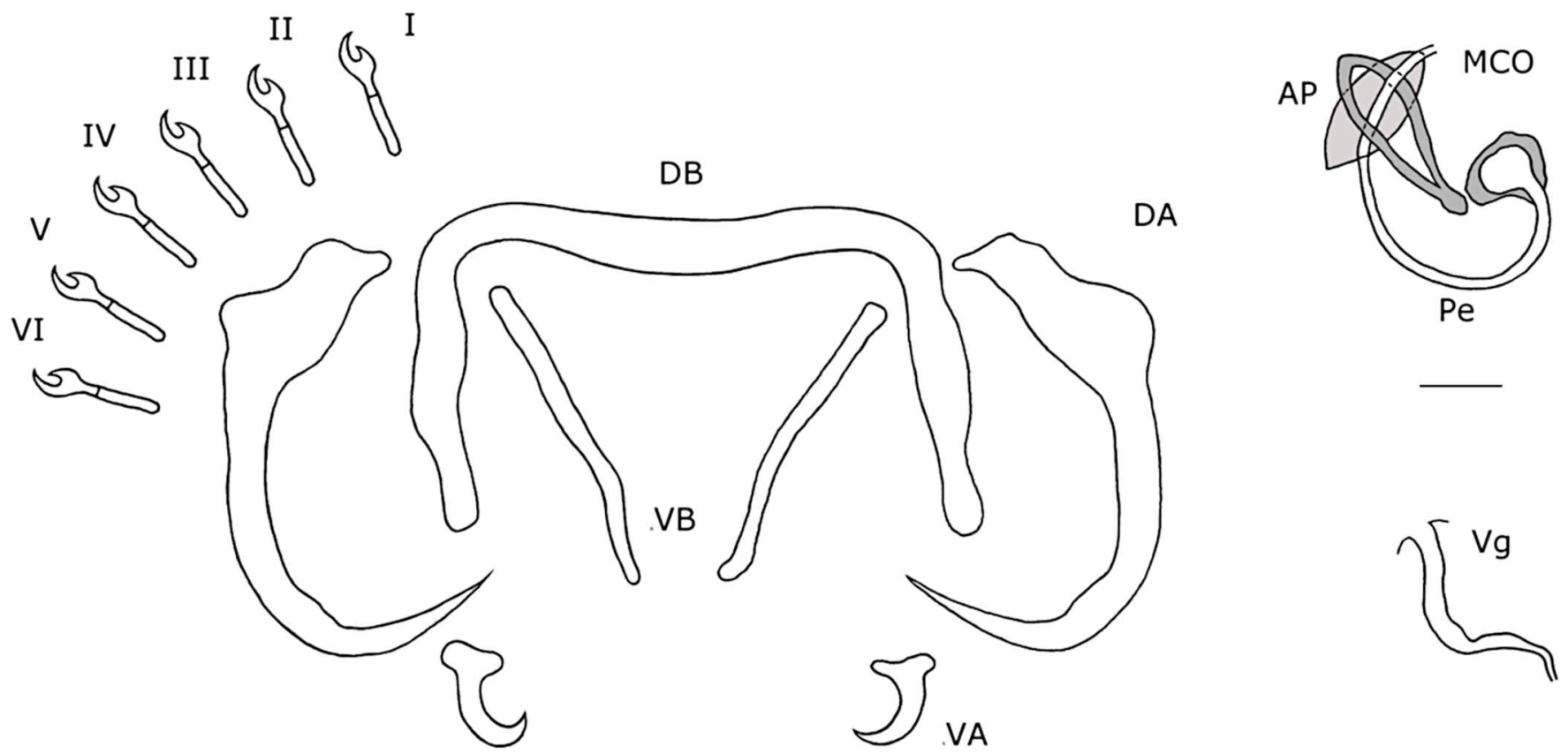

Figure 11. Haptoral and genital hard parts of Onchobdella ximenae n. sp. from Hemichromis elongatus. Accessory piece of the MCO in grey, to highlight the plate-like structure of the accessory piece. I-VI, hooks; AP, accessory piece; DA, dorsal anchors; DB, dorsal transverse bar; MCO, male copulatory organ; Pe, penis; VA, ventral anchors; VB, ventral transverse bars; Vg, vagina. Scale bar: $20 \mu \mathrm{m}$, scale bar of the MCO $10 \mu \mathrm{m}$.

course. A rounded, irregularly-shaped heel engulfs the basal bulb, except where the penis transitions into the basal bulb. Accessory piece consists of two rib-like structures that form an ellipsoid (resembling a windsurf wishbone), through which the penis passes. Both rib-like structures come together proximally, where they form a small bulge and distally, where their connection is smooth. At the distal end of the penis a leaf-like, smooth-edged plate is present, and is orientated perpendicular to the ellipsoid. Vagina, small, with two $90^{\circ}$ curves, tubular (L $=33 \mu \mathrm{m})$.

\section{Remarks}

Onchobdella ximenae n. sp. resembles $O$. voltensis Paperna, 1968, described from Lake Volta, Ghana from $H$. fasciatus and $H$. bimaculatus. Both $O$. ximenae n. sp. and $O$. voltensis have ventral bars with solid distal ends instead of filamentous ends, such as are seen in all other congeners. Furthermore, both species have an accessory piece that forms an ellipsoid, a penis that passes through it and a smooth, leaf-like plate at the distal end of the accessory piece. The differences between these species are that the dorsal anchors in $O$. ximenae n. sp. are 10-40 $\mu \mathrm{m}$ smaller (see Table 5) and have an undeveloped shaft. The ventral anchors have a T-shaped base, contrary to the ones in $O$. voltensis, which have a base that is orientated proximally and not laterally. The penis of $O$. voltensis is J-shaped, whilst in O. ximenae n. sp. it almost makes a loop and is 16-36 $\mu \mathrm{m}$ longer (see Table 5). Also, the leaf-shaped plate is orientated perpendicularly on the ellipsoid, while in $O$. voltensis it follows the orientation of the ellipsoid. Lastly, $O$. voltensis does not have a sclerotized vagina.

\section{Discussion}

Seventeen species of monogeneans, eight of which are new for science, were collected from five host species. Six of these new parasite species are described. For $C$. reversati, slight variations in morphology are mentioned as well as a ridge on the accessory piece. Two undescribed parasites, $C$. sp. 1 and $C$. sp.2, were also found in the Middle Congo Basin and will be described in the report from that expedition.

\section{Parasites of Coptodon}

From the Tondé estuary (see Fig. 1), the non-native Coptodon rendalli was captured [10]. Its native range includes tributaries and parts of the Middle and Upper Congo, the Zambezi, Cuanza, Catumbela, Okavango and Cunene rivers [10]. In Lower Congo, Coptodon rendalli was infected by Cichlidogyrus berradae Pariselle \& Euzet, 2003; Cichlidogyrus cubitus Dossou, 1982 and Cichlidogyrus flexicolpos Pariselle \& Euzet, 1995 (see Table 1). These species have not been found on Coptodon rendalli before, but on other representatives of Coptodon from Benin, Ivory Coast, Cabinda and the ROC [35]. Additionally, parasite species known from Coptodon rendalli from other regions, such as Cichlidogyrus dossoui Douëllou, 1993; Cichlidogyrus quaestio Douëllou, 1993; Cichlidogyrus papernastrema Price, Peebles \& Bamford, 1969 or Cichlidogyrus tiberianus Paperna, 1960 [7, 14, 46] were not found in Lower Congo. This indicates that Coptodon rendalli lost its original parasite fauna during or after introduction, supporting the enemy-release hypothesis [38]. When 
comparing the parasite fauna of the native Coptodon tholloni with that of Coptodon rendalli in this study, only C. cubitus is shared between the two hosts. However, our sample size is small and, therefore, it is presumable that more parasite species are shared. Cichlidogyrus cubitus does not occur in the native range of Coptodon rendalli, so it is possible that Coptodon rendalli acquired this parasite through a spillback effect from Coptodon tholloni [11]. The same applies for C. flexicolpos on Coptodon rendalli. However, the reservoir for $C$. flexicolpos in Lower Congo could also be Coptodon guineensis, since there are no records of C. flexicolpos on Coptodon tholloni. Furthermore, Coptodon guineensis is known to host $C$. flexicolpos [29] and to occur in the mangroves of Lower Congo [10]. In our study, Gyrodactylus chitandiri Zahradníčková, Barson, Luus-Powell and Přikrylová, 2016 infected Coptodon tholloni, which constitutes a new host and geographical record and results in a disjunct distribution for $G$. chitandiri. The parasite is known from Coptodon rendalli and Pseudocrenilabrus philander (Weber, 1897) from Chirundu, Zambezi River and Lake Kariba [49], whilst it was lacking in Upper Congo on both hosts [14]. Instead, Coptodon rendalli was infected by Gyrodactylus nyanzae Paperna, 1973 in Upper Congo [14]. The disjunct distribution of $G$. chitandiri could be biased due to limited sampling in the past. From our observations, species of Gyrodactylus are far less prevalent (occurring on one out of 14 infected cichlid specimens in Lower Congo and on 1 out of 12 in Upper Congo) than species of Cichlidogyrus on gills of African cichlids, so it is easy to miss species of Gyrodactylus during sampling. We hypothesize that $G$. chitandiri shows a continuous distribution from the Zambezi Basin to Lower Congo. It should be noted that although their minimum prevalence is lower than that of species of Cichlidogyrus, their infection intensity is often higher (see Table 2 in this study and [14]). One specimen of Coptodon tholloni from the Ndimba Leta ponds, Mbanza-Ngungu (locality 3, Fig. 1) was exclusively infected by Cichlidogyrus tilapiae Paperna, 1960. This parasite is a generalist (see [21]), but has mostly been found on mouth-brooding cichlids (Oreochromini, see [8]) and has a wide native range that spans most of Central and western Africa, and the Levant [14, 27, 35]. Several species of Coptodon have been screened previously for parasites (e.g. Coptodon rendalli from Upper Congo [14, 46]), but of these, C. tilapiae has only been found on Coptodon zillii, so far [9]. In the case of the C. tilapiae infection on Coptodon zillii, O. niloticus was also present in the area [9], which is also the case in the Ndimba-Leta ponds. Whether the infection of C. tilapiae on Coptodon tholloni is natural or a result of spillover (see [45] and references therein) has to be determined in future research. If the infection is the result of spillover, this would support the hypothesis of Jorissen et al. [14], that certain aquatic systems, such as ponds or artificial lakes, stimulate interspecies interactions between cichlid hosts and have a higher host density, both of which stimulate parasite hostswitching.

\section{Parasites of Hemichromis}

The collected representatives of Hemichromis are the native $H$. elongatus and $H$. stellifer [10]. On these hosts, we have discovered three new species that are morphologically similar to already described ones: $O$. ximenae n. sp., which resembles $O$. voltensis; $C$. calycinus n. sp., which resembles $C$. teugelsi and $C$. polyenso n. sp., which resembles $C$. euzeti [35]. Furthermore, we can assume from the literature that C. euzeti is sympatric (occurs on the same individual host) with $C$. longicirrus in Benin, Cameroon and ROC, though not explicitly stated [6, 22, 34], while in Lower Congo, $C$. longicirrus is sympatric with $C$. polyenso n. sp. Similarly, $O$. voltensis and $O$. aframae are presumably sympatric in Benin, Cameroon, Senegal, Gambia, Mali and Ivory Coast $[6,26,34]$, while in Lower Congo $O$. aframae is sympatric with $O$. ximenae n. sp. As shown, there are similarities between the parasite faunas of Hemichromis spp. throughout different ecoregions. However, parasites of Hemichromis spp. remain unexplored for large portions of Africa; thus, it is too early to draw conclusions about their biogeography and diversity. Nonetheless, it can be hypothesized that compared with the species discovered in Lower Congo, more morphologically similar species exist in other freshwater ecoregions on other representatives of Hemichromis. Cichlidogyrus kmentovae $\mathrm{n}$. sp. was only found on $H$. stellifer, but our sample size is too small to verify whether it does not infect $H$. elongatus as well. Cichlidogyrus falcifer occurs on H. fasciatus [35] as well as on H. elongatus and thus is an intermediate specialist (a parasite occurring on more than one host from the same genus, see [21]).

\section{Parasites of Tylochromis praecox}

From Tylochromis praecox, C. bixlerzavalai n. sp. and C. omari n. sp. are described. New species were expected as no monogeneans had yet been described from $T$. praecox. Furthermore, all dactylogyrids from species of Tylochromis mentioned in the literature are considered strict specialists $[14,23,35,36]$, meaning, they occur on a single host species. In those studies, representatives of Tylochromis were caught in low numbers and restricted to a single host species. In Lower Congo, Tylochromis labrodon Regan, 1920 and Tylochromis lateralis (Boulenger, 1898) occur further upstream and are sympatric, but not with T. praecox [43]. It would be worthwhile to investigate whether $C$. bixlerzavalai $\mathrm{n}$. $\mathrm{sp}$. and C. omari n. sp. occur on these hosts as well, to see if these parasites are all strict specialists or if they only appear to be so because of biogeographical barriers. The ancestral state for host-specificity within Cichlidogyrus/Scutogyrus is intermediate specialism [21]. Species of Cichlidogyrus that infect species of Tylochromis are shown to be ancestral to all others within Cichlidogyrus/Scutogyrus [19-21, 37, 48], similar to Tylochromis (and Tylochromini) being ancestral to all African cichlids except Heterochromis [8, 43]. We could hence hypothesize that species of Cichlidogyrus that infect species of Tylochromis are intermediate specialists when sympatric host congeners are present in the area. It has to be noted that only Cichlidogyrus pouyaudi Pariselle \& Euzet, 1994 was included as a representative that infects species of Tylochromis in the phylogenies of Cichlidogyrus/Scutogyrus [19-21, 37, 48]. However, we expect species of Cichlidogyrus that infect species of Tylochromis to form a monophyletic clade based 
on the morphological similarities between the species [37]. Both new species showed typical morphological characters of their congeners that infect species of Tylochromis, such as less developed auricles on the dorsal transverse bar, an accessory piece that does not connect directly to the basal bulb of the penis, and a spirally-winding penis [23, 28]. Following the phylogeny, we assume these morphological characters to be ancestral to all others within Cichlidogyrus/ Scutogyrus [37].

\section{Species richness and comparison with other regions}

Half of the parasite species found in this study are new to science, which is high in comparison to the single new species described from the Mweru-Luapula subregion in the Upper Congo Basin [14]. This can partially be explained by the Lower Congo region being more diverse and having many biogeographical barriers that facilitate speciation $[15,16]$. In addition, almost all host species in the Lower Congo region were screened for parasites for the first time. Also, most of the cichlid species studied in the Mweru-Luapula subregion had a more widespread distribution than the ones in Lower Congo [10], and thus it was more likely for us to find previouslydescribed parasites [14]. The diversity of monogenean parasites outmatches that of their hosts by more than 3:1 in this study, which is in line with the African average of 3.1 [44]. The parasite fauna reported in this study has more species in common with ecoregions from other basins, such as the nearby OgoouéNyanga-Kouilou-Niari ecoregion than with the rest of the Congo Basin. A possible explanation for this is that the Lower Congo was not a part of the Congo Basin until the Early Quaternary [42] and has stayed isolated from the rest of the Congo Basin because of the biogeographical barriers that the region is known for [15, 16, 24, 42]. Furthermore, representatives of Tylochromis and Hemichromis have predominantly been screened from Ghana, Benin, Cameroon, Senegal, Gambia, Mali, Guinea and Ivory Coast [6, 25, 26, 28, 34], whilst most parts of the Congo Basin or Central Africa remain unexplored. These genera have their origins in West Africa [18]. Furthermore, the parasite fauna of $P$. cabrae from the coastal lowlands of the ROC was reported to be highly homogeneous with that of West African cichlid hosts [33], so it is possible that an overlap in monogenean biodiversity between these two regions exists. Our results support this claim.

\section{Note}

Michiel Jorissen won the prize for the best student presentation at the 8th International Symposium on Monogenea, held on 6-11 August 2017 at Masaryk University, Faculty of Science, Brno, Czech Republic, which was a fee-waiver for a paper in Parasite. The cost of publication of the present paper was thus offered by EDP Sciences.

\section{Conflict of interest}

The authors declare that there is no conflict of interest.
Acknowledgements. This research was supported by the Belgian Federal Science Policy Office (BRAIN-be Pioneer Project (BR/132/PI/TILAPIA), OCA type II project S1_RDC_TILAPIA and the Mbisa Congo project, the latter two being framework agreement projects of the RMCA with the Belgian Development Cooperation. MWPJ is supported by a BOF Reserve Fellowship from Hasselt University. The research leading to results presented in this publication was carried out with infrastructure funded by EMBRC Belgium - FWO project GOH3817N. Fieldwork was carried out under mission statements AC/075/2015/I.S.P./MBNGU/AUT.AC and AC/076/2015/I.S.P./MBNGU/AUT.AC. We cordially thank Marcel Collet, Paul N'Lemvo (Institut Congolais pour la Conservation de la Nature), Dieudonné Kufulu-ne-Kongo (école Muilu Kiawanga), L'or Matondo Mbela (Université Kongo), Prosper Nguizani Bimbundi, Boble Boki Fukiakanda and general director father Pierre Ntiama Nsiku (Institut Supérieur Pédagogique de MbanzaNgungu) and Placide Nzialu Mahinga (Institut National pour l'Etude et la Recherche Agronomiques - Mvuazi/Institut Supérieur d'études agronomiques - Mvuazi) for administrative, field and lab support, making this study possible. MPMV received support from the Belgian Directorate-General for Development Cooperation and Humanitarian Aid (CEBioS programme at the Royal Belgian Institute of Natural Sciences) and the Czech Science Foundation (P505/ 12/G112 (ECIP)). We would like to thank Eileen Harris, Timo Pajunen, Christophe Allard and Albé Bosman for their curatorial services. We would like to thank Nikki Watson for her grammatical input concerning this manuscript. Lastly, we would like to thank the two anonymous reviewers and Jean-Lou Justine (Editor-in-chief) for their constructive remarks.

\section{References}

1. Abell $\mathrm{R}$, Thieme $\mathrm{M}$, Revenga $\mathrm{C}$, Bryer $\mathrm{M}$, Kottelat $\mathrm{M}$, Bogutskaya N, Coad B, Mandrak N, Contreras-Balderas S, Bussing W, Stiassny MLJ, Skelton P, Allen GR, Unmack P, Naseka A, Ng R, Sindorf N, Robertson J, Armijo E, Higgins J, Heibel TJ, Wikramanayake E, Olson D, Lopez HL, Reis REd, Lundberg JG, Sabaj Perez MH, Petry P. 2008. Freshwater Ecoregions of the World: a new map of biogeographic units for freshwater biodiversity conservation. Bioscience, 58, 403-414.

2. Alter SE, Brown B, Stiassny ML. 2015. Molecular phylogenetics reveals convergent evolution in lower Congo River spiny eels. BMC Evolutionary Biology, 15, 224.

3. Bates J. 1997. The sealing compound: Glyceel. Journal of Nematology, 29(4), 565-566.

4. Bilong Bilong CF, Euzet L. 1995. Onchobdella bopeleti n. sp. (Monogenea, Ancyrocephalidae) parasite branchial de Hemichromis fasciatus (Peters, 1857) (Cichlidae). Journal of African Zoology, 109(5), 253-258.

5. Birgi E, Euzet L. 1983. Monogènes parasites des poissons des eaux douces du Cameroun. Présence des genres Cichlidogyrus et Dactylogyrus chez Aphyosemion (Cyprinodontidae). Bulletin de la Société Zoologique de France, 108(1), 101-106.

6. Dossou C, Birgi E. 1984. Monogènes parasites d'Hemichromis fasciatus Peters, 1857 (Teleostei, Cichlidae). Annales des Sciences Naturelles, Zoologie, Paris, 6(2), 101-109.

7. Douëllou L. 1993. Monogeneans of the genus Cichlidogyrus Paperna, 1960 (Dactylogyridae, Ancyrocephalinae) from cichlid fishes of Lake Kariba (Zimbabwe), with descriptions of five new species. Systematic Parasitology, 25, 159-186.

8. Dunz AR, Schliewen UK. 2013. Molecular phylogeny and revised classification of the haplotilapiine cichlid fishes formerly referred to as "Tilapia". Molecular Phylogenetics and Evolution, 68(1), 64-80. 
9. Ergens R. 1981. Nine species of the genus Cichlidogyrus Paperna, 1960 (Monogenea: Ancyrocephalinae) from Egyptian fishes. Folia Parasitologica, 28, 205-214.

10. Froese R, Pauly D. 2015. Fishbase, www.fishbase.org.

11. Goedknegt MA, Feis ME, Wegner KM, Luttikhuizen PC, Buschbaum C, Camphuysen K, van der Meer J, Thieltges DW. 2016. Parasites and marine invasions: Ecological and evolutionary perspectives. Journal of Sea Research, 113, 11-27.

12. Harris PD, Shinn AP, Cable J, Bakke TA. 2004. Nominal species of the genus Gyrodactylus von Nordmann 1832 (Monogenea: Gyrodactylidae), with a list of principal host species. Systematic Parasitology, 59(1), 1-27.

13. ICZN ICoZN. 1999. International Code of Zoological Nomenclature, www.nhm.ac.uk/hosted-sites/iczn/code/.

14. Jorissen MWP, Pariselle A, Huyse T, Vreven EJ, Snoeks J, Volckaert FAM, Manda AC, Kasembele GK, Artois T, Vanhove MPM. 2018. Diversity and host specificity of monogenean gill parasites (Platyhelminthes) of cichlid fishes in the BangweuluMweru ecoregion. Journal of Helminthology, 92(4), 417-437.

15. Lowenstein JH, Osmundson TW, Becker S, Hanner R, Stiassny MLJ. 2011. Incorporating DNA barcodes into a multi-year inventory of the fishes of the hyperdiverse Lower Congo River, with a multi-gene performance assessment of the genus Labeo as a case study. Mitochondrial DNA, 22(sup1), 52-70.

16. Markert AJ, Schelly RC, Stiassny ML. 2010. Genetic isolation and morphological divergence mediated by high-energy rapids in two cichlid genera from the lower Congo rapids. BMC Evolutionary Biology, 10(1), 149-158.

17. Markevitch AC. 1934. Parasitic diseases of fish and their control (in Russian). Leningrad: Koiz Publishing. 100p.

18. Mayer WE, Tichy H, Klein J. 1998. Phylogeny of African cichlid fishes as revealed by molecular markers. Heredity, 80, 702-714.

19. Mendlová M, Desdevises Y, Civáňová K, Pariselle A, Šimková A. 2012. Monogeneans of West African cichlid fish: evolution and cophylogenetic interactions. PLoS One, 7(5), 1-17.

20. Mendlová M, Pariselle A, Vyskočilová M, Šimková A. 2010. Molecular phylogeny of monogeneans parasitizing African freshwater Cichlidae inferred from LSU rDNA sequences. Parasitology Research, 107(6), 1405-1413.

21. Mendlová M, Šimková A. 2014. Evolution of host specificity in monogeneans parasitizing African cichlid fish. Parasites and Vectors, 7, 69.

22. Messu Mandeng FD, Bilong Bilong CF, Pariselle A, Vanhove MPM, Bitja Nyom AR, Agnese JF. 2015. A phylogeny of Cichlidogyrus spp. (Monogenea, Dactylogyridea) clarifies a host-switch between fish families and reveals an adaptive component to attachment organ morphology of this parasite genus. Parasites and Vectors, 8, 582.

23. Muterezi Bukinga F, Vanhove MPM, Van Steenberge M, Pariselle A. 2012. Ancyrocephalidae (Monogenea) of Lake Tanganyika: III: Cichlidogyrus infecting the world's biggest cichlid and the non-endemic tribes Haplochromini, Oreochromini and Tylochromini (Teleostei, Cichlidae). Parasitology Research, 111(5), 2049-2061.

24. Oberg K, Shelton JM, Gardiner N, Jackson PR. 2009. Discharge and other hydraulic measurements for characterizing the hydraulics of Lower Congo River, Proceedings of the International Association for Hydraulic Research Congress. p. 1-8.

25. Paperna I. 1965. Monogenetic Trematodes collected from fresh water in Southern Ghana. Bamidgeh, Bulletin of Fish Culture in Israel, 17(4), 107-111.

26. Paperna I. 1968. Onchobdella n. gen. New genus of Monogenetic trematodes (Dactylogyridae, Bychowksi 1933) from Cichlid fish from West Africa. Proceedings of the Helminthological Society of Washington, 35(2), 200-206.
27. Paperna I, Thurston JP. 1969. Monogenetic trematodes collected from cichlid fish in Uganda; including the description of five new species of Cichlidogyrus. Revue de Zoologie et de Botanique Africaines, 79(1/2), 15-33.

28. Pariselle A, Euzet L. 1994. Three new species of Cichlidogyrus Paperna, 1960 (Monogenea, Ancyrocephalidae) parasitic on Tylochromis jentinki (Steindachner, 1895) (Pisces, Cichlidae) in West Africa. Systematic Parasitology, 29(3), 229-234.

29. Pariselle A, Euzet L. 1995. Gill parasites of the genus Cichlidogyrus Paperna, 1960 (Monogenea, Ancyrocephalidae) from Tilapia guineensis (Bleeker, 1862), with descriptions of six new species. Systematic Parasitology, 30, 187-198.

30. Pariselle A, Euzet L, . 1995. Scutogyrus gen. n. (Monogenea: Ancyrocephalidae) for Cichlidogyrus longicornis minus Dossou, 1982, C. l. longicornis, and C. l. gravivaginus Paperna and Thurston, 1969, with description of three new species parasitic on African cichlids. Journal of the Helminthological Society of Washington, 62(2), 157-173.

31. Pariselle A, Euzet L. 1995. Trois monogènes nouveaux parasites branchiaux de Pelmatochromis buettikoferi (Steindachner, 1895) (Pisces, Cichlidae) en Guinée. Parasite, 2, 203-209.

32. Pariselle A, Euzet L. 1996. Cichlidogyrus Paperna, 1960 (Monogenea, Ancyrocephalidae): gill parasites from West African Cichlidae of the subgenus Coptodon Regan, 1920 (Pisces), with descriptions of six new species. Systematic Parasitology, 34, 109-124.

33. Pariselle A, Euzet L. 2003. Four new species of Cichlidogyrus (Monogenea: Ancyrocephalidae), gill parasites of Tilapia cabrae (Teleostei: Cichlidae), with discussion on relative length of haptoral sclerites. Folia Parasitologica, 50(3), 195-201.

34. Pariselle A, Euzet L. 2004. Two new species of Cichlidogyrus Paperna, 1960 (Monogenea, Ancyrocephalidae) gill parasites on Hemichromis fasciatus (Pisces, Cichlidae) in Africa, with remarks on parasite geographical distribution. Parasite, 11(4), 359-364.

35. Pariselle A, Euzet L. 2009. Systematic revision of dactylogyridean parasites (Monogenea) from cichlid fishes in Africa, the Levant and Madagascar. Zoosystema, 31(4), 849-898.

36. Pariselle A, Bitja Nyom AR, Bilong Bilong CF. 2014. Four new species of Cichlidogyrus (Monogenea, Ancyrocephalidae) from Sarotherodon mvogoi and Tylochromis sudanensis (Teleostei, Cichlidae) in Cameroon. Zootaxa, 3881(3), 258-266.

37. Pouyaud L, Desmarais E, Deveney M, Pariselle A. 2006. Phylogenetic relationships among monogenean gill parasites (Dactylogyridea, Ancyrocephalidae) infesting tilapiine hosts (Cichlidae): systematic and evolutionary implications. Molecular Phylogenetics and Evolution, 38(1), 241-249.

38. Prenter J, Macneil C, Dick JT, Dunn AM. 2004. Roles of parasites in animal invasions. Trends in Ecology and Evolution, 19(7), 385-390.

39. Pugachev ON, Gerasev PI, Gussev AV, Ergens R, Khotenowsky I. 2009. Guide to Monogenoidea of freshwater fish of Palearctic and Amur regions. Ledizioni Ledipublishing: Milan. 538 p.

40. Rahmouni C, Vanhove MPM, Šimková A. 2017. Underexplored diversity of gill monogeneans in cichlids from Lake Tanganyika: eight new species of Cichlidogyrus Paperna, 1960 (Monogenea: Dactylogyridae) from the northern basin of the lake, with remarks on the vagina and the heel of the male copulatory organ . Parasites and Vectors, 10, 591.

41. Řehulková E, Mendlová M, Šimková A. 2013. Two new species of Cichlidogyrus (Monogenea: Dactylogyridae) parasitizing the gills of African cichlid fishes (Perciformes) from Senegal: morphometric and molecular characterization. Parasitology Research, 112(4), 1399-1410. 
42. Stankiewicz J, de Wit MJ. 2006. A proposed drainage evolution model for Central Africa - Did the Congo flow east? Journal of African Earth Sciences, 44(1), 75-84.

43. Stiassny ML. 1989. A taxonomic revision of the African genus Tylochromis (Labroidei: Cichlidae); with notes on anatomy and relationships of the groups. Annalen Zoölogische Wetenschappen, Koninklijk Museum voor Midden-Afrika, 258, $1-161$.

44. Vanhove MPM, Hablützel PI, Pariselle A, Šimková A, Huyse T, Raeymaekers JAM. 2016. Cichlids: a host of opportunities for evolutionary parasitology. Trends in Parasitology, $32(10), 820-832$.

45. Vanhove MPM, Huyse T. 2015. Host specificity and species jumps in fish-parasite systems, in Parasite diversity and diversification. Morand S, Krasnov BR, Littlewood DTJ, Editors. Cambridge University Press: Cambridge. p. 401-419.

46. Vanhove MPM, Van Steenberge M, Dessein S, Volckaert FAM, Snoeks J, Huyse T, Pariselle A. 2013. Biogeographical implications of Zambezian Cichlidogyrus species (Platyhelminthes: Monogenea: Ancyrocephalidae) parasitizing Congolian cichlids. Zootaxa, 3608, 398-400.

47. Vignon M, Pariselle A, Vanhove MPM. 2011. Modularity in attachment organs of African Cichlidogyrus (Platyhelminthes: Monogenea: Ancyrocephalidae) reflects phylogeny rather than host specificity or geographic distribution. Biological Journal of the Linnean Society, 102, 694-706.

48. Wu XY, Zhu XQ, Xie MQ, Li AX. 2007. The evaluation for generic-level monophyly of Ancyrocephalinae (Monogenea, Dactylogyridae) using ribosomal DNA sequence data. Molecular Phylogenetics and Evolution, 44, 530-544.

49. Zahradničková P, Barson M, Luus-Powell WJ, Přikrylová I. 2016. Species of Gyrodactylus von Nordmann, 1832 (Platyhelminthes: Monogenea) from cichlids from Zambezi and Limpopo river basins in Zimbabwe and South Africa: evidence for unexplored species richness. Systematic Parasitology, 93(7), 679-700.

Cite this article as: Jorissen MWP, Pariselle A, Huyse T, Vreven EJ, Snoeks J, Decru E, Kusters T, Lunkayilakio SW, Bukinga FM, Artois T \& Vanhove MPM. 2018. Six new dactylogyrid species (Platyhelminthes, Monogenea) from the gills of cichlids (Teleostei, Cichliformes) from the Lower Congo Basin. Parasite 25, 64.

\section{PARASTE}

An international open-access, peer-reviewed, online journal publishing high quality papers on all aspects of human and animal parasitology

Reviews, articles and short notes may be submitted. Fields include, but are not limited to: general, medical and veterinary parasitology; morphology, including ultrastructure; parasite systematics, including entomology, acarology, helminthology and protistology, and molecular analyses; molecular biology and biochemistry; immunology of parasitic diseases; host-parasite relationships; ecology and life history of parasites; epidemiology; therapeutics; new diagnostic tools.

All papers in Parasite are published in English. Manuscripts should have a broad interest and must not have been published or submitted elsewhere. No limit is imposed on the length of manuscripts.

Parasite (open-access) continues Parasite (print and online editions, 1994-2012) and Annales de Parasitologie Humaine et Comparée (1923-1993) and is the official journal of the Société Française de Parasitologie. 